\title{
STREAMFLOW AND WATER-QUALITY DATA FOR LAKE PURDY AND ITS TRIBUTARIES, JEFFERSON AND SHELBY COUNTIES, ALABAMA, WATER YEARS 1987-91
}

By V.E. Stricklin

U.S. GEOLOGICAL SURVEY

Open-File Report 93-498

Prepared in cooperation with the

WATER WORKS AND SEWER BOARD

OF THE CITY OF BIRMINGHAM 


\section{U.S. DEPARTMENT OF THE INTERIOR}

BRUCE BABBITT, Secretary

U.S. GEOLOGICAL SURVEY

ROBERT M. HIRSCH, Acting Director

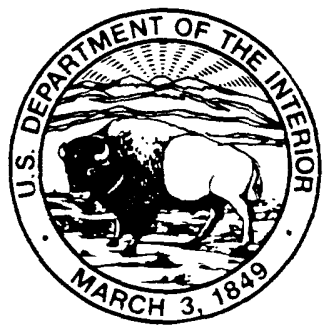

For additional information write to:

District Chief

U.S. Geological Survey

520 19th Avenue

Tuscaloosa, Alabama 35401
Copies of this report can be purchased from:

U.S. Geological Survey

Earth Science Information Center

Open-File Reports Section

Box 25286, MS 517, Federal Center

Denver, Colorado 80225 


\section{CONTENTS}

Page

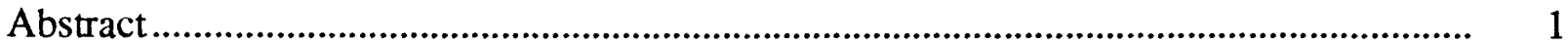

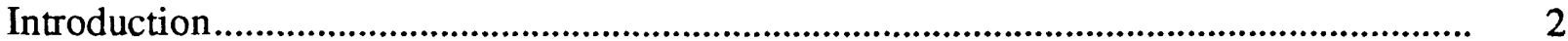

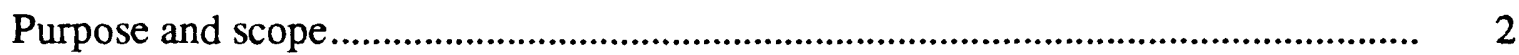

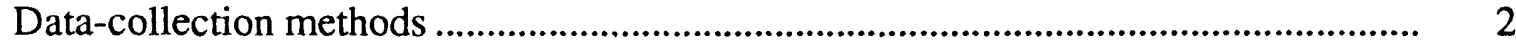

Description of the study area ................................................................................ 5

Streamflow .................................................................................................... 5

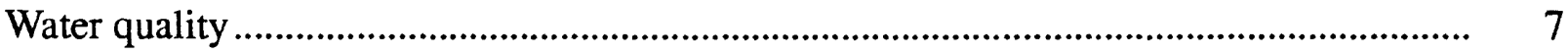

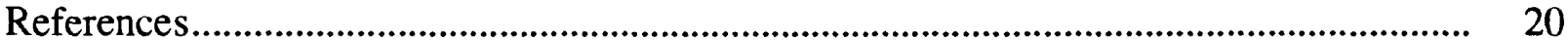

\section{ILLUSTRATIONS}

Figure 1.Map showing location of study area.............................................................. 3

2. Map showing location of data-collection sites ......................................... 4

3. Diagram showing generalized surface geology of the study area ....................... 6

4-13.Box plots showing:

4. Specific conductance at selected sites in Lake Purdy drainage basin ............... 8

5. $\mathrm{pH}$ at selected sites in Lake Purdy drainage area .......................................... 9

6. Alkalinity at selected sites in Lake Purdy drainage area................................ 10

7. Dissolved oxygen at selected sites in Lake Purdy drainage area ...................... 11

8. Water temperature measured at selected sites in Lake Purdy drainage area...... 12

9. Total recoverable iron measured at selected sites in Lake Purdy drainage area.. 13

10. Calcium at selected sites in Lake Purdy drainage basin ................................. 14

11. Sodium at selected sites in Lake Purdy drainage basin .................................... 15

12. Chloride at selected sites in Lake Purdy drainage basin ................................... 16

13. Sulfate at selected sites in Lake Purdy drainage basin ................................... 17

14. Piper diagram of variation in water chemistry between all Lake Purdy and selected tributaries sites for the period of record

\section{TABLES}

(Located in back of report)

Table 1. Summary of surface-water data collection network

2. Annual mean discharges in decreasing order for water years 1987-91

3. Summary of water-quality analyses at sampling sites in Lake Purdy basin, water years 1987-91 


\section{CONVERSION FACTORS}

Multiply

inch

foot

mile

square mile

acre

cubic foot per second

ton per day

gallon
By

25.4

0.3048

1.609

2.590

0.4047

0.02832

0.90718

3.785
To obtain

millimeter

meter

kilometer

square kilometer

hectare

cubic meter per second metric ton per day cubic meter

Temperature is degrees Celsius $\left({ }^{\circ} \mathrm{C}\right)$ can be converted to degrees Fahrenheit $\left({ }^{\circ} \mathrm{F}\right)$ as follows: ${ }^{\circ} \mathrm{F}=1.8\left({ }^{\circ} \mathrm{C}\right)+32$. 


\title{
STREAMFLOW AND WATER-QUALITY DATA FOR LAKE PURDY AND ITS TRIBUTARIES JEFFERSON AND SHELBY COUNTIES, WATER YEARS 1987-91
}

\author{
By V.E. Stricklin
}

\begin{abstract}
Lake Purdy was created in 1911 by the impoundment of the Little Cahaba River and is used primarily as a supplemental water supply for the city of Birmingham and surrounding communities. Changes in land use, such as residential development and disposal of industrial waste within the basin, have caused concern about possible changes in water quality of the lake and its tributaries.

Ten sites in the Lake Purdy Basin chosen for this study included six inflow sites, three lake sites, and one site at the outflow of the lake. Data collected during the study indicate that the Little Cahaba River provides approximately 80 percent of the total annual mean inflow to the lake. The Little Cahaba River drains 24.4 square miles, which represents 57 percent of the drainage area at the lake outlet. During the 1988 water year, a severely dry year, the Little Cahaba River provided approximately 88 percent of the total mean inflow into Lake Purdy. During the 1988 water year, daily mean inflow to Lake Purdy was 21.9 cubic feet per second and the mean outflow from the lake was 31.1 cubic feet per second.

All constituents analyzed throughout the study area were within drinking-water limits except for total recoverable iron, total recoverable and dissolved manganese, and $\mathrm{pH}$. The maximum concentration of total recoverable iron occurred at Lee Branch (site 6) and the maximum concentration for total recoverable manganese occurred at Little Cahaba River below Lake Purdy (site 10). The maximum concentration of total recoverable iron and total recoverable manganese occurred at Lee Branch (site 6). The maximum $\mathrm{pH}$ was at Lake Purdy at Irondale Bridge (site 4) and Lake Purdy near Cahaba Heights (site 9) and the minimum pH was at Cox Creek (site 5).

Lake Purdy demonstrated minor spatial variation in water quality from the northern most lake site at Irondale Bridge (site 4), to the southern sites at U.S. Highway 119 (site 7), and at Lake Purdy Dam (site 9). The northern part of the lake is heavily influenced by the major contributor, Little Cahaba River, which has a consistently higher dissolved ion concentration than any other tributary to the lake. The southern part of the lake is buffered by Cox Creek, Lee Branch, and the unnamed tributary to Ike Pond Slough, which all have consistently lower dissolved ion concentrations than that of the lake.
\end{abstract}




\section{INTRODUCTION}

Lake Purdy, located in Jefferson and Shelby Counties in north-central Alabama, was created in 1911 by the impoundment of the Little Cahaba River (fig. 1). The principle function of Lake Purdy is to supplement the Birmingham water supply at the Cahaba River pump station on the Cahaba River about 2.8 miles southwest of the dam (fig. 2). The original dam was constructed at a height of 40 feet and created a lake with a storage capacity of 1.5 billion gallons. In 1929, an additional 20 feet was added to the height of the dam, increasing the lake's storage capacity to 5.7 billion gallons and surface area to 1,050 acres.

Changes in land use and streamflow, due to development within the basin, cause concern for the quantity and quality of the water in the basin and reservoir. The city of Leeds has discharged sewage effluent into the Little Cahaba River upstream from Lake Purdy since 1936. Industrial effluents are also discharged in the river in the vicinity of Leeds. Suburban expansion in the Little Cahaba River Basin has accelerated during the data collection period, resulting in an increase in disposal of domestic sewage through septic tanks.

\section{Purpose and Scope}

In 1986, a monitoring program was established by the U.S. Geological Survey, in cooperation with the Birmingham Water Works, to collect water quantity and quality data of Lake Purdy inflow and outflow. This report summarizes streamflow and water-quality data for Lake Purdy and its tributaries for water years 1987-91.

The hydrologic data provide a basis to assess effects of current and future land-use changes within the basin. Streamflow and water-quality data were collected at 10 sites in the Little Cahaba River Basin (fig. 2; table 1).

\section{Data-Collection Methods}

All water samples were collected using depth-integrated sampling techniques as discussed by Guy and Norman (1970). Samples requiring filtration were filtered through a 0.45 -micron filter. Preservation, as required, was performed onsite. Nutrient samples were preserved with mercuric chloride and chilled to $4{ }^{\circ} \mathrm{C}$. Samples for major cations were preserved with nitric acid and samples for trace metals were preserved with nitric acid and potassium dichromate. Field determinations of discharge (except for sites 4, 7, and 9) (fig. 2), specific conductance, $\mathrm{pH}$, dissolved oxygen, water temperature, alkalinity, fecal coliform, and fecal streptococcal bacteria were made at the time of sampling. Chemical analyses were performed by the U.S. Geological Survey.

Continuous streamflow data were collected at Little Cahaba River near Jefferson Park (site 1), Cox Creek near Cahaba Heights (site 5), and Little Cahaba River below Lake Purdy Dam near Cahaba Heights (site 10). Streamflow data were collected in conformance with methods described by Rantz and others (1982a, 1982b). 


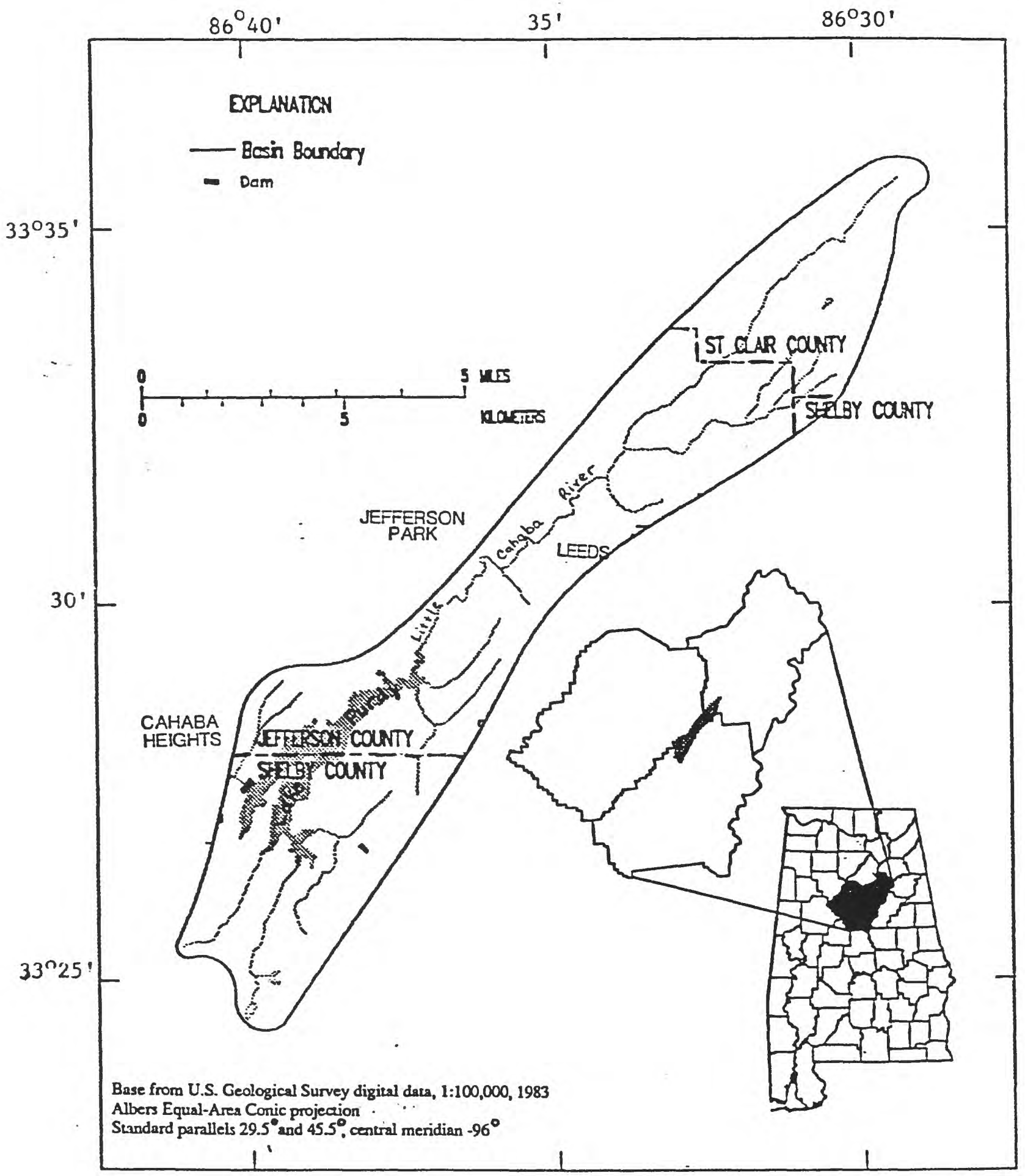

Figure 1.--Location of study area. 


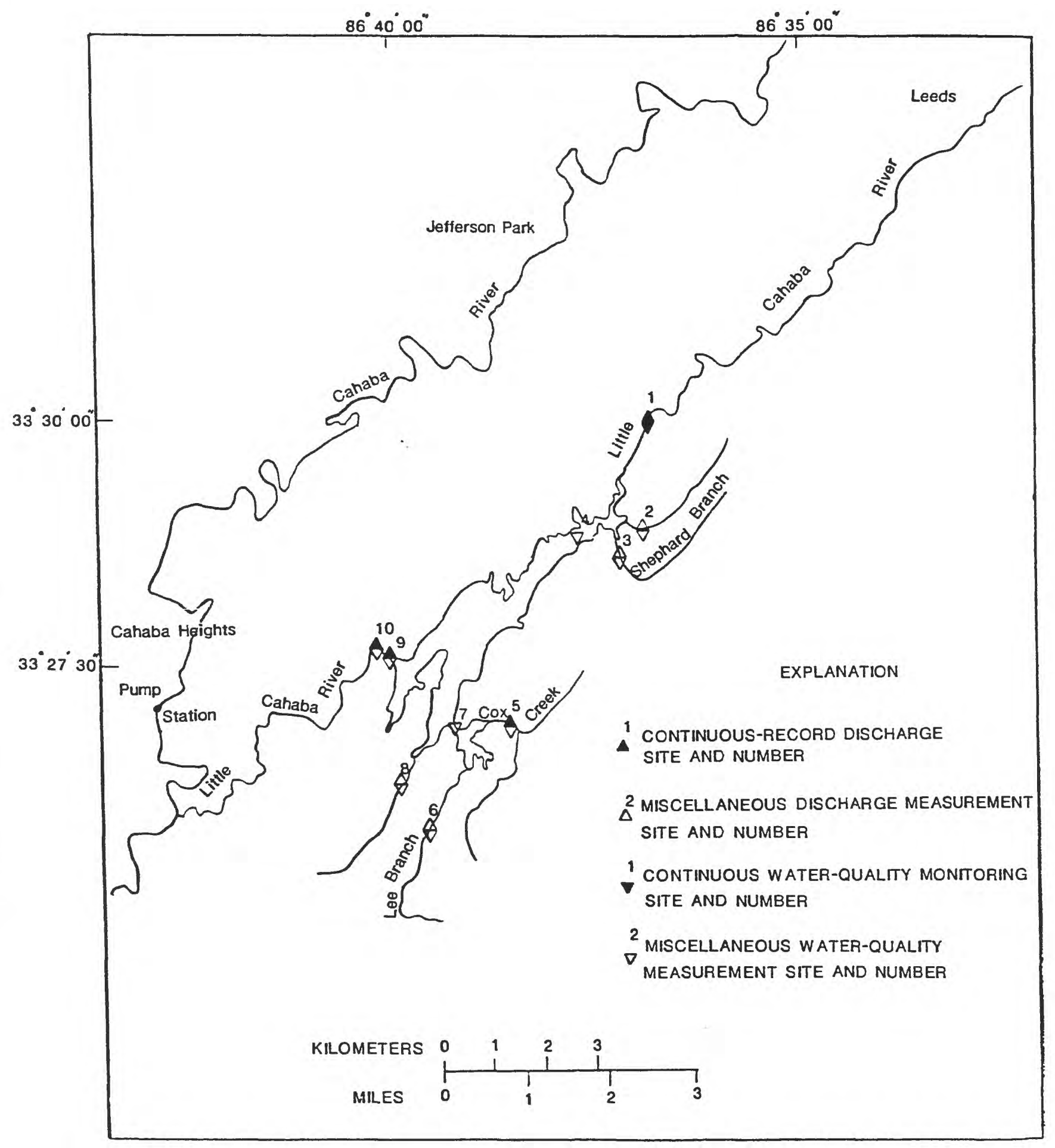

Figure 2.--Location of data-collection sites. 


\section{DESCRIPTION OF THE STUDY AREA}

The Lake Purdy Basin is located in the Cahaba Valley physiographic district of the Alabama Valley and Ridge section of the Appalachian Valley and Ridge Province (Fenneman, 1938). The selected tributaries within the Lake Purdy Basin, as well as the lake, are underlain predominately by limestone of Ordovician age and dolomite of the Knox Group of Ordovician age (Kidd, 1972; Butts, 1927). The exception is Cox Creek, which flows through the sideritic and calcareous Floyd Shale (Mississippian) (fig. 3). These strata within the basin are folded and faulted to form resistant sandstone-capped ridges and valleys of less resistant limestone and shales, as reflected by the trellis drainage patterns in the basin (fig. 2).

The study area has a subtropical climate that is characterized by warm, humid summers and relatively mild winters. Precipitation is usually in the form of rain, with little or no snowfall. March usually is the wettest month of the year and October is the driest. Average annual precipitation during the study period was 52.8 inches at Leeds (U.S. Department of Commerce, 1987-91). The driest year during the data collection period was 1988 when 43.05 inches of rain was recorded (U.S. Department of Commerce, 1988). The wettest year was 1989 when 61.09 inches of rain was recorded (U.S. Department of Commerce, 1989). Long-term evaporation data are not available for the Lake Purdy area, but Peirce (1955) reported that a coefficient of 0.7 could be applied to pan data to estimate evaporation from bodies of water larger than this lake. Using this coefficient, approximately 40 inches per year of free-water evaporation would occur in the Lake Purdy Basin.

The Little Cahaba River Basin upstream from Lake Purdy is sparsely populated except for the city of Leeds in the upper part of the drainage basin. Development within the lower part of the basin has increased steadily since 1986. Most of the land in the basin is forested, but some areas have been cleared for pasture land.

\section{STREAMFLOW}

Inflow to Lake Purdy is primarily from the Little Cahaba River, Shephard Branch, Cox Creek, Lee Branch, and two unnamed tributaries to the Little Cahaba River (fig. 2). Except for Little Cahaba River, streams flowing into Lake Purdy typically go dry in late spring (May) and either remain dry or flow intermittently until around November. Streamflow is highest during the months of December through April when precipitation is greatest and transpiration from vegetation is least. The valley of the Little Cahaba Basin above Lake Purdy is underlain predominately by limestone and dolomite that are moderately cavernous (Kidd, 1979). These formations provide most of the dry-weather flow to the lake through springs or seeps within these formations (Johnston, 1933). The tributaries are underlain mainly by shale and sandstone that provide little dry-weather flow.

Monthly mean discharges for ungaged sites were estimated using a method developed by Riggs (1969) which is based on the assumption that the ratio of concurrent daily mean flows of two streams near the middle of the month approximates the ratio of their means for that month. Monthly measurements at the ungaged sites (sites 2,3, and 6) were used with daily discharge records at Cox Creek to estimate monthly means for the ungaged sites. 


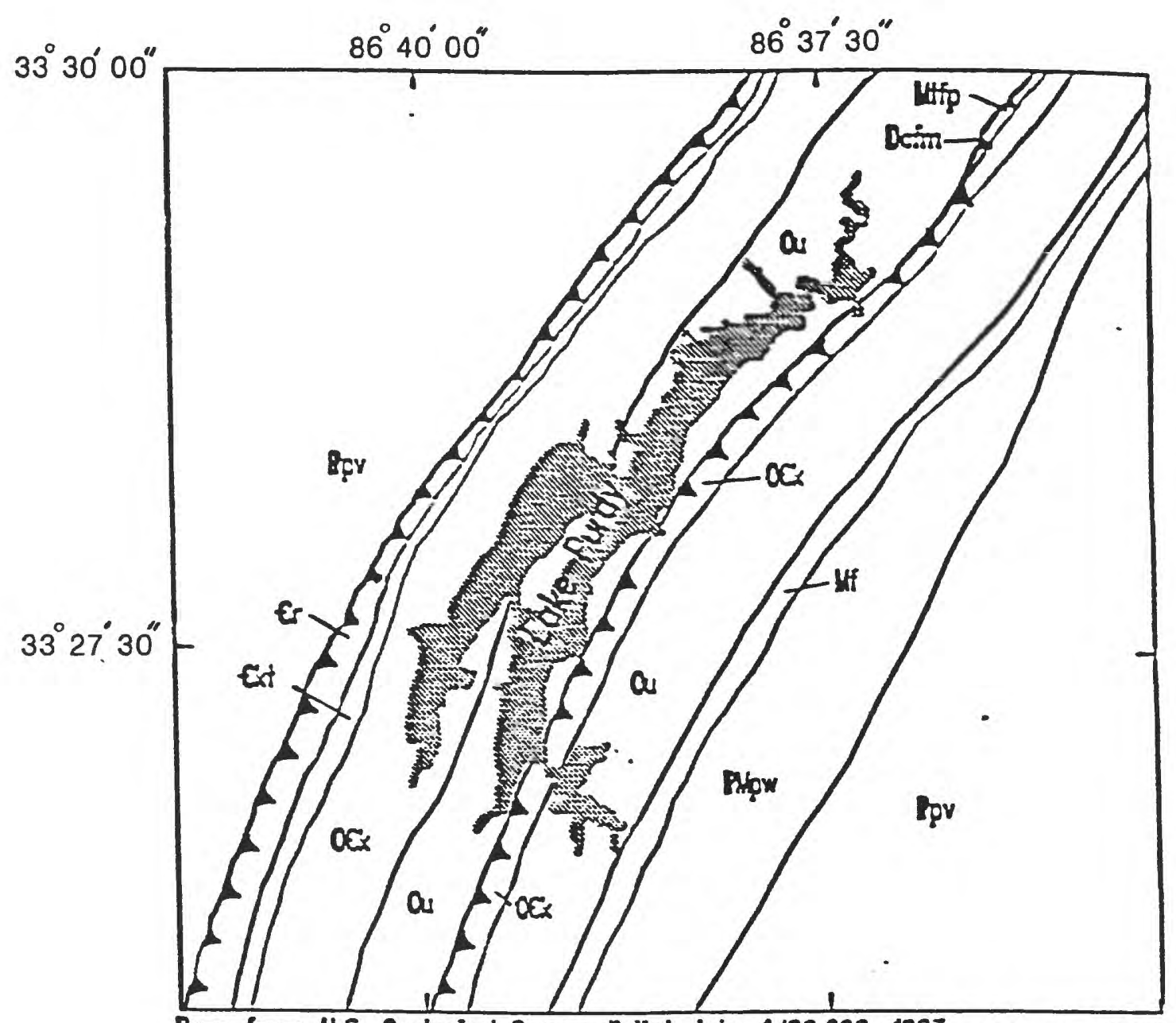

Bose from U.S. Geologicad Survey digital dato, k!00,000, 1983 Goology modifed from Albars Equal-dra Conic projection

Siandard porallels $29.5^{\circ}$ and $45.5^{\circ}$. ceniral meridian $-96^{\circ} \quad$ Caades Buts, 1927

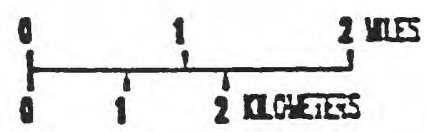

\section{EPULนTOH}

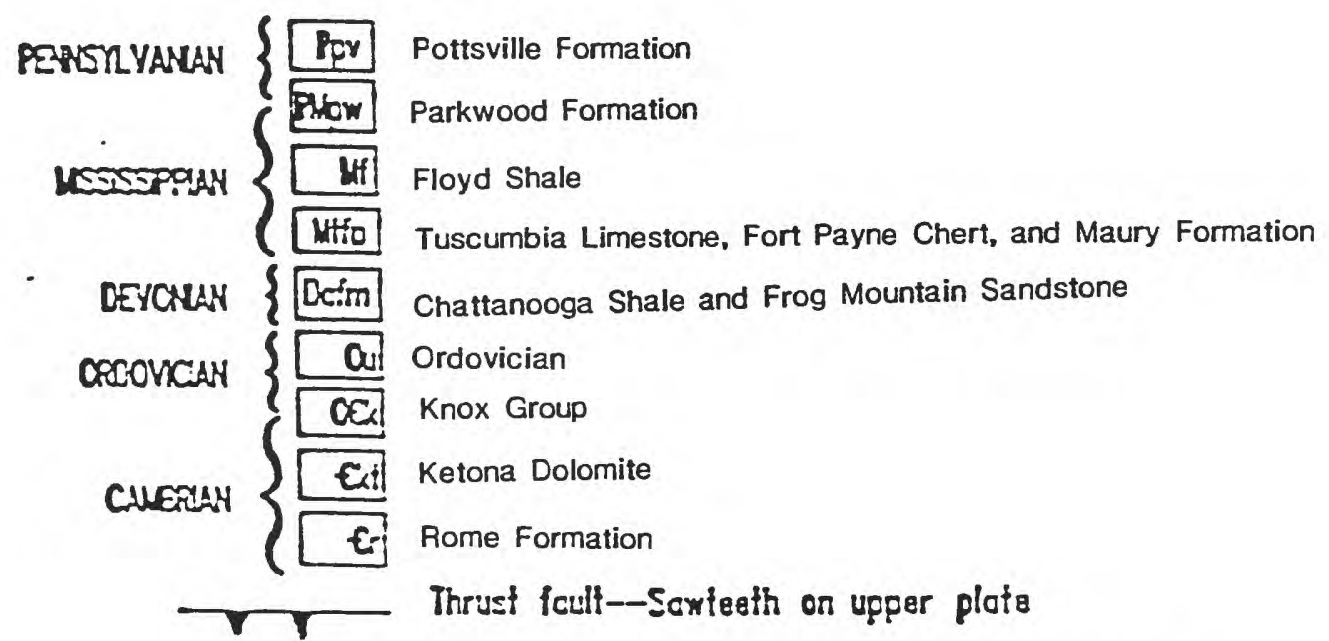

Figure 3.- Gznerafized surfacs geclogy of the siudy arec. 
Annual mean discharges for the ungaged sites were calculated as arithmetic averages of the estimated monthly mean discharges (table 2). Annual mean discharges for stations at Little Cahaba River near Jefferson Park and Cox Creek near Cahaba Heights were determined from daily discharge records at these sites. Based on these calculations, more than 80 percent of the total inflow into Lake Purdy was supplied by the Little Cahaba River, which drains about 57 percent of the drainage area at the lake outlet. Discharge for Little Cahaba River during the 1987 water year, a relatively normal year of precipitation (U.S. Department of Commerce, 1950-91), contributed about 80 percent of the total inflow to the lake. During the 1988 water year, a severely dry year, Little Cahaba River provided about 90 percent of the total inflow. Inflow from Cox Creek during 1987 and 1988 was 10 and 6 percent of the total inflow, respectively.

\section{WATER QUALITY}

Water samples were collected at 10 sites within the Lake Purdy Basin from October 1986 to September 1991 to establish baseline water-quality conditions in the basin. The sampling locations included six major tributaries, sites on the lake, and one site approximately 600 feet below (downstream of) the dam on the Little Cahaba River. The range and median values of selected water-quality constituents or properties of the samples are listed in table 3.

Box plots were used to compare the water quality of Lake Purdy with that of its tributaries (figs. 4-13). These plots also depict the amount of temporal variation and any non-normal distribution (skewness) in these parameters and water chemistry during the sample period (1987-91). The box graphically displays the position of the middle 50 percent of the data, with a bar crossing at the median. The constituent values on the box plots representing the 75th and 25th percentiles are shown as the horizontal lines at the top and bottom of the box, respectively. All data lying outside the selected interval (lower quartile minus 1.5 times the interquartile range; upper quartile plus 1.5 times the interquartile range) are plotted individually as outliers (Klein and Graedel, 1980).

Lake Purdy had only minor spatial variation in water quality from the northern site at Irondale Bridge (site 4) to the southern sites (east, site 7; west, site 9). Specific conductance, $\mathrm{pH}$, and alkalinity decreased from site 4 to site 9 . However, much overlap existed between the distribution ranges for all lake sites, with the exception of sulfate and sodium concentrations. These minor variations in water chemistry of the three lake sites were attributed to the contributing streams at each site.

The water chemistry of Lake Purdy at Irondale Bridge site (site 4) in the northern part of the basin reflects contributions from all three tributaries (Little Cahaba River, site 1; unnamed tributary, site 2; Shephard Branch, site 3). The major dissolved ion concentrations are generally higher at site 1 than site 2 or site 3 with the exception of dissolved iron concentrations, which have a greater distribution and higher median concentration at Shephard Branch (site 3). The amount of temporal variation in Lake Purdy water quality at this site also appears to reflect contributions from all three stream sites, with water quality at the unnamed tributary being the least variable for all constituents. 


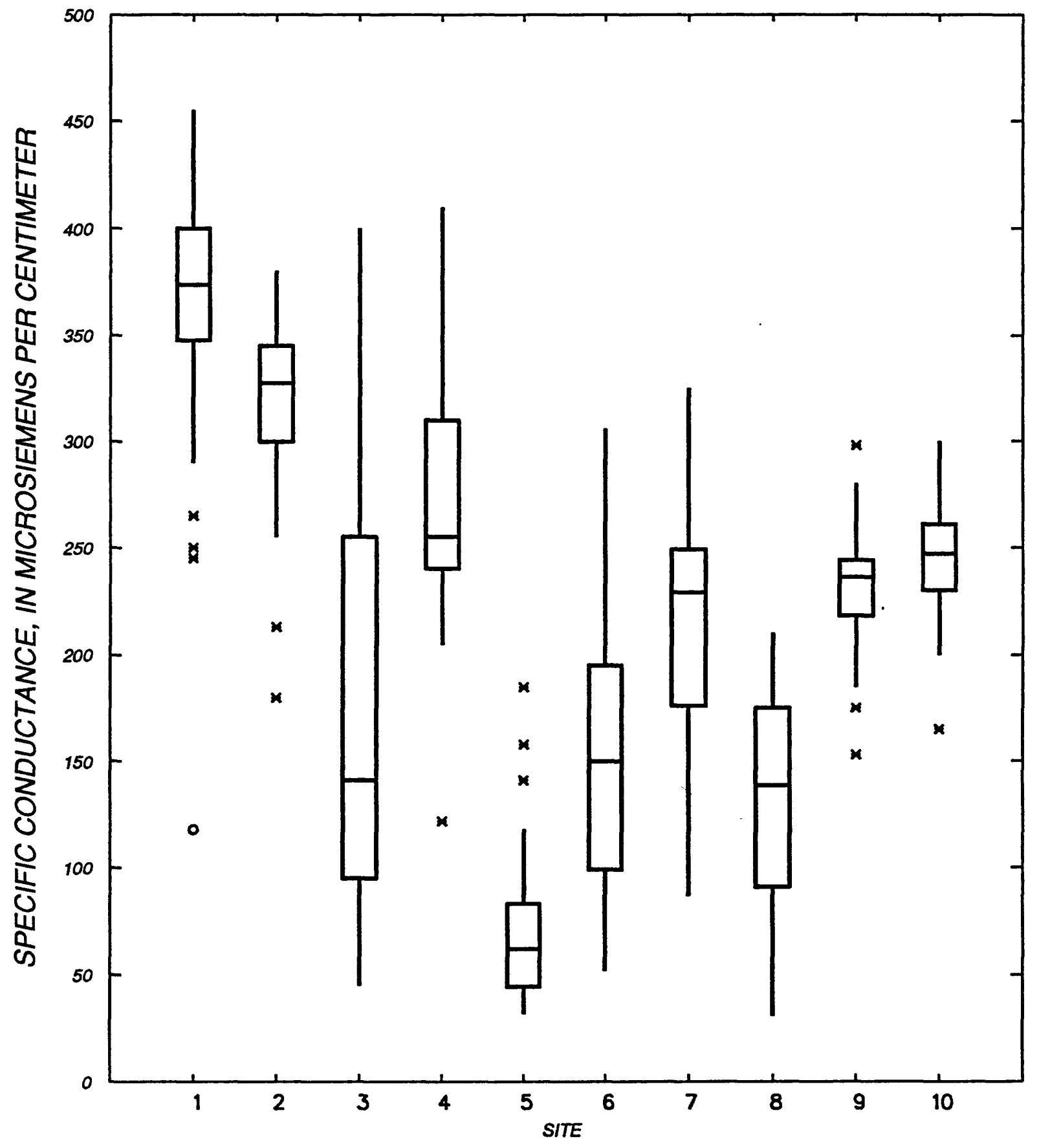

Figure 4.-- Box plot of specific conductance at selected sites in Lake Purdy drainage basin. 


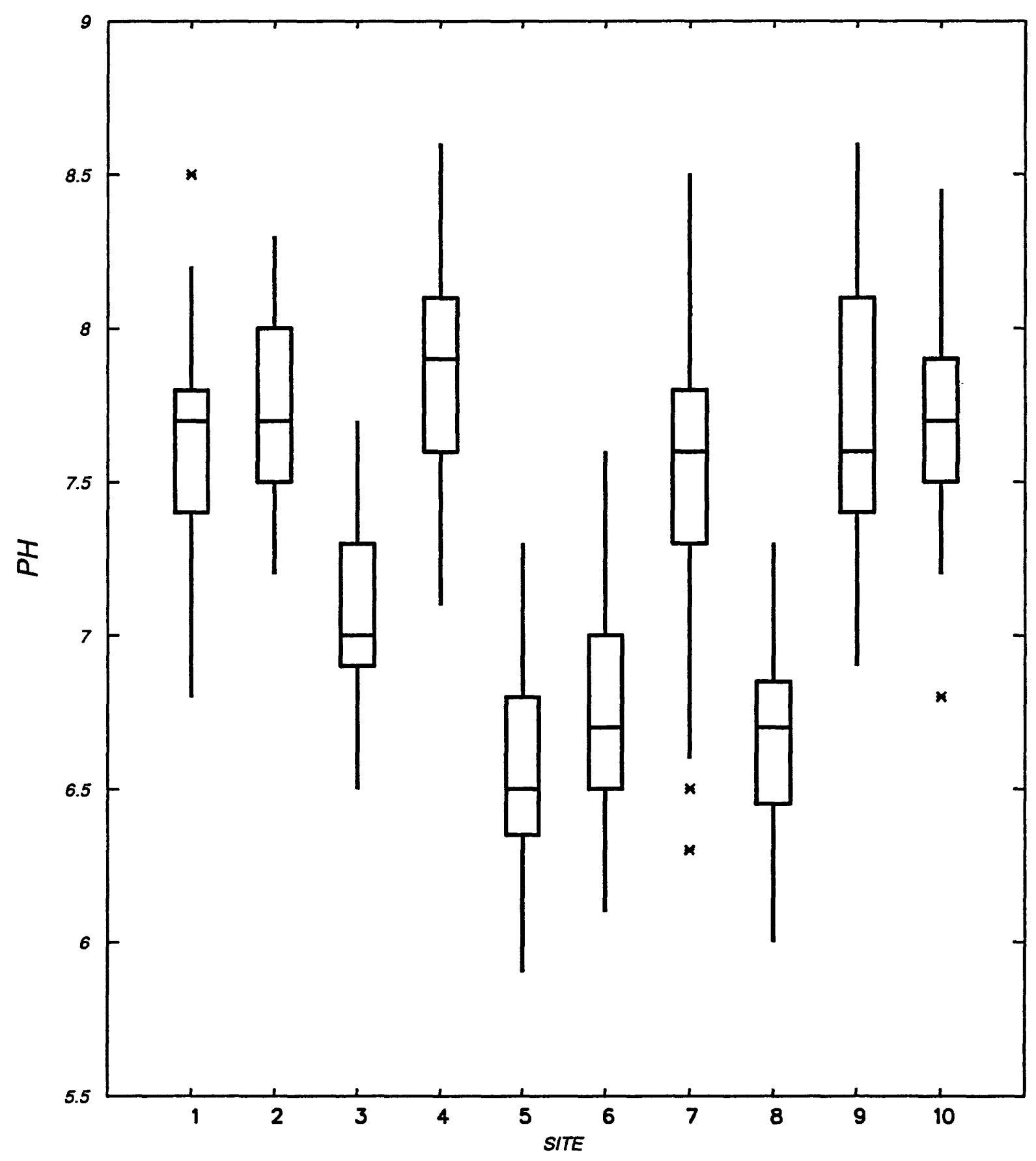

Figure 5.-- Box plot of $\mathrm{pH}$ at selected sites in Lake Purdy drainage basin. 


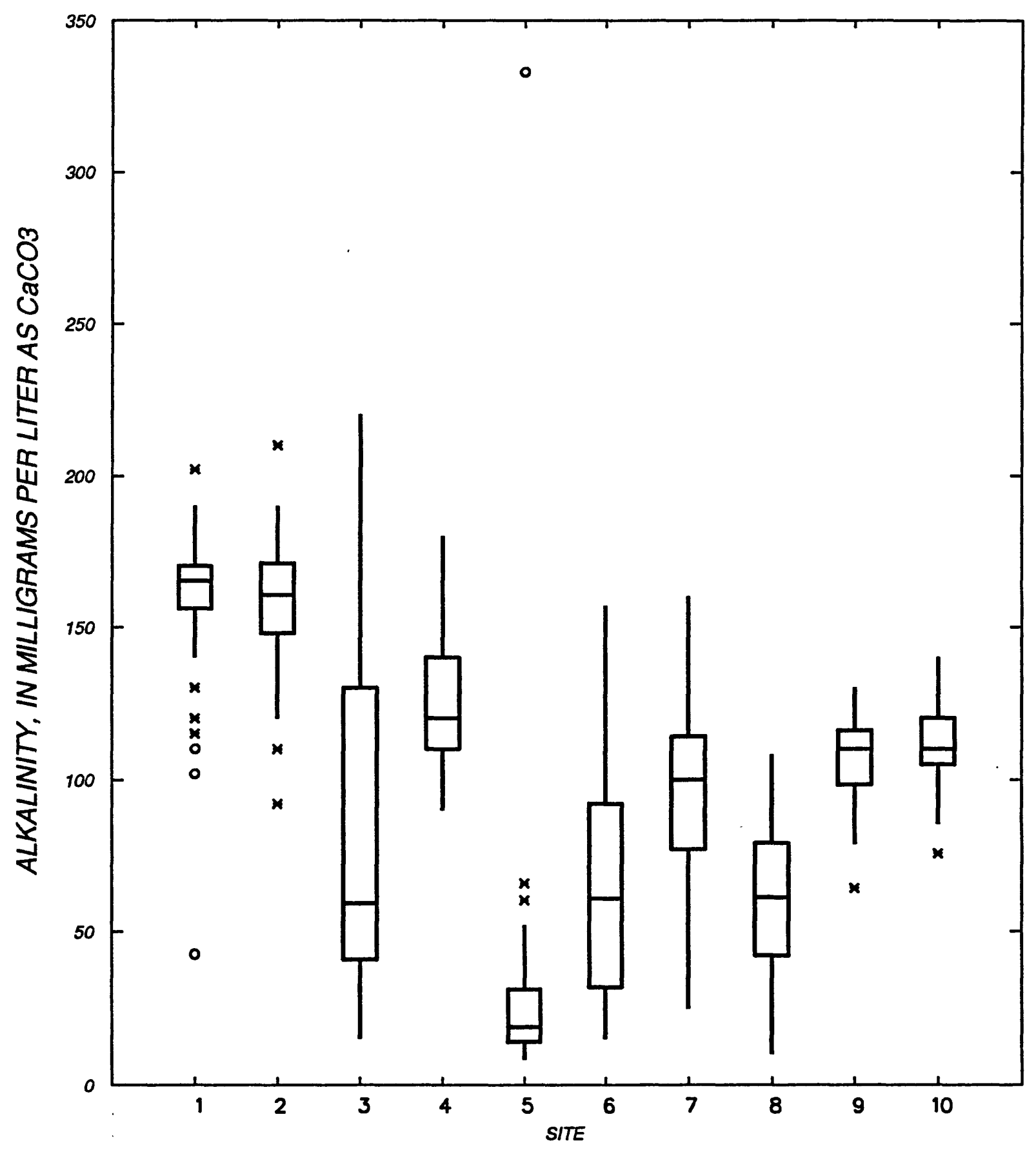

Figure 6.-- Box plot of alkalinity at selected sites in Lake Purdy drainage basin. 


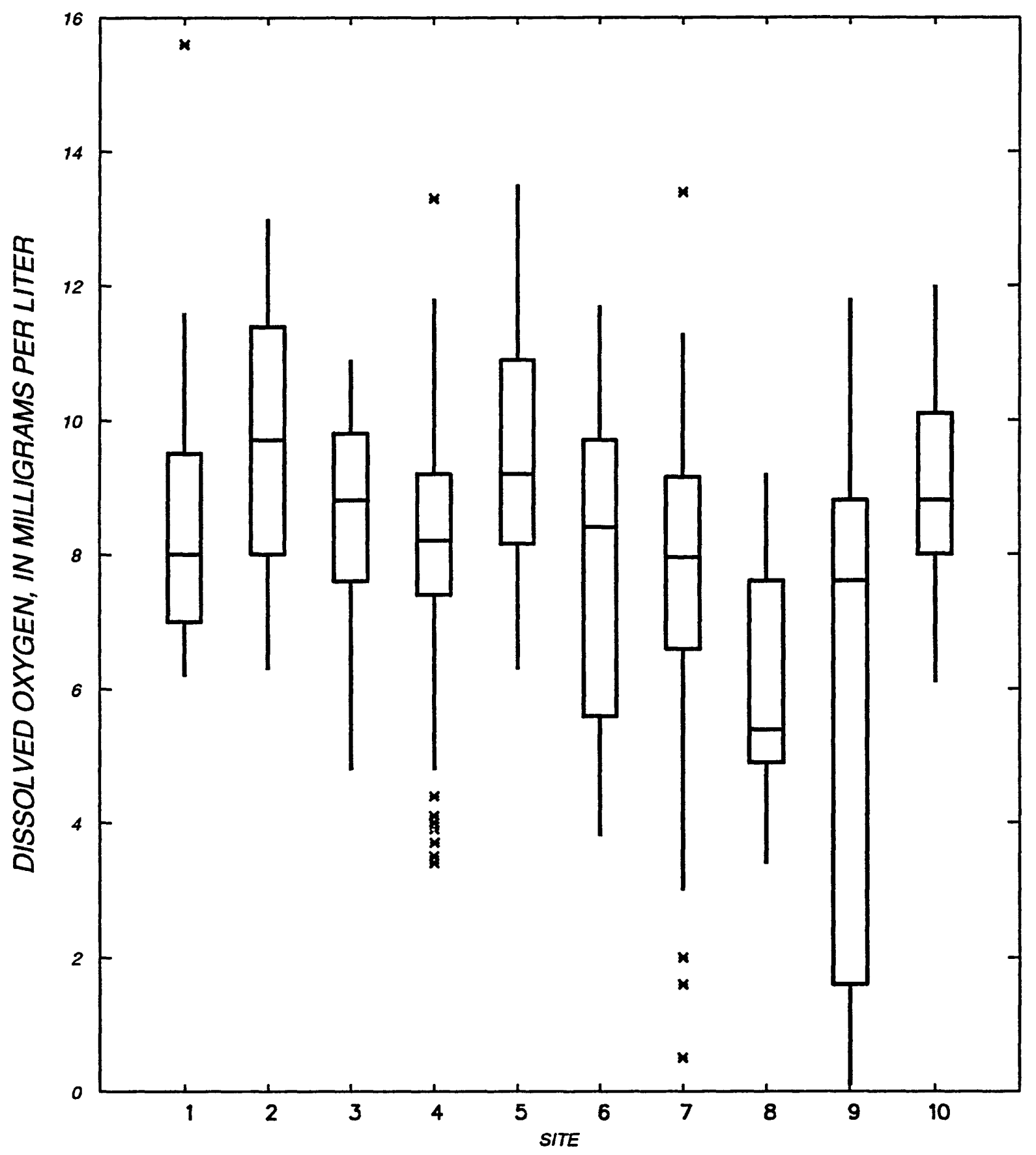

Figure 7.-- Box plot of dissolved oxygen at selected sites in Lake Purdy drainage basin. 


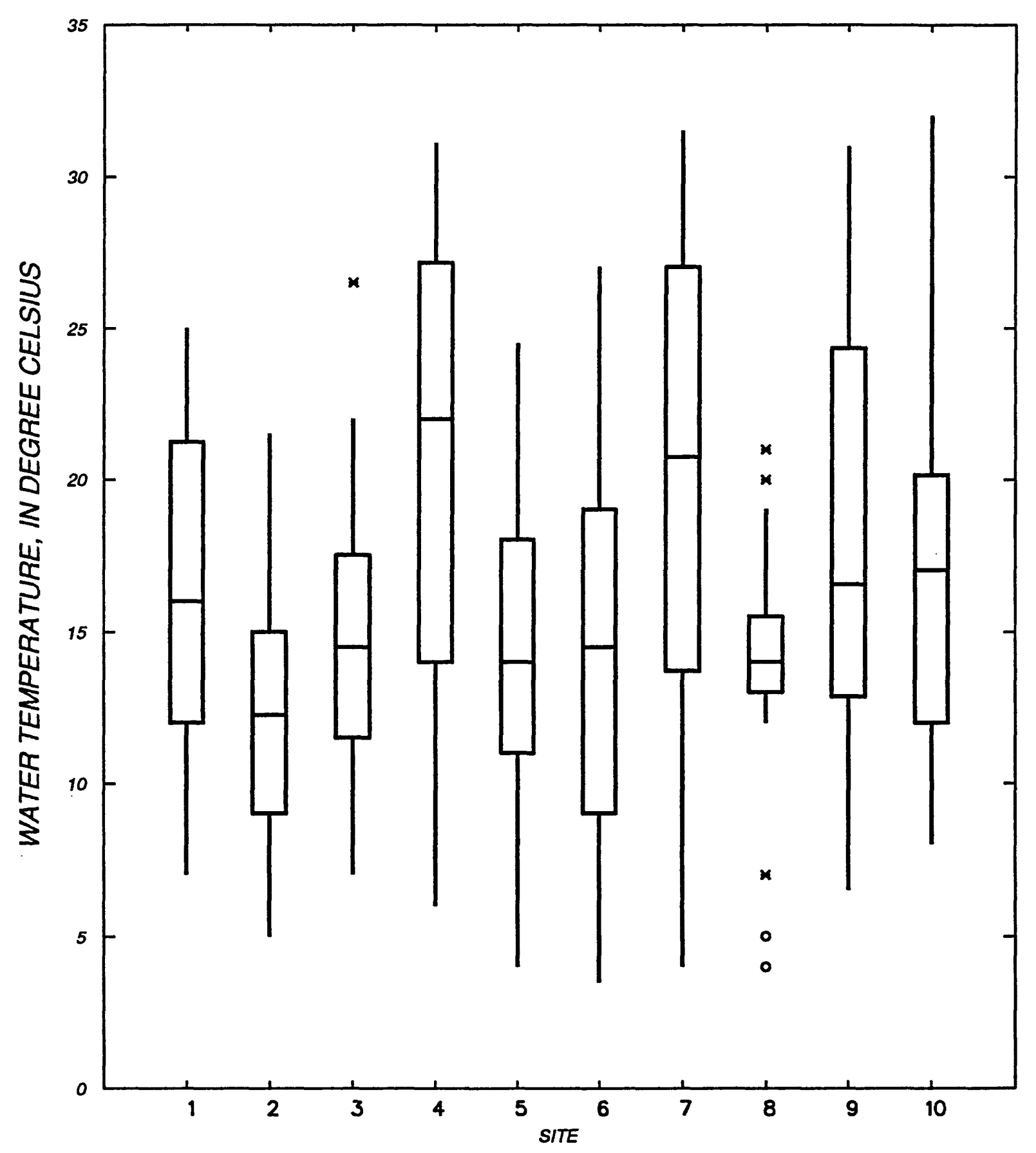

Figure 8.-- Box plot of water temperature at selected sites in Lake Purdy drainage basin. 


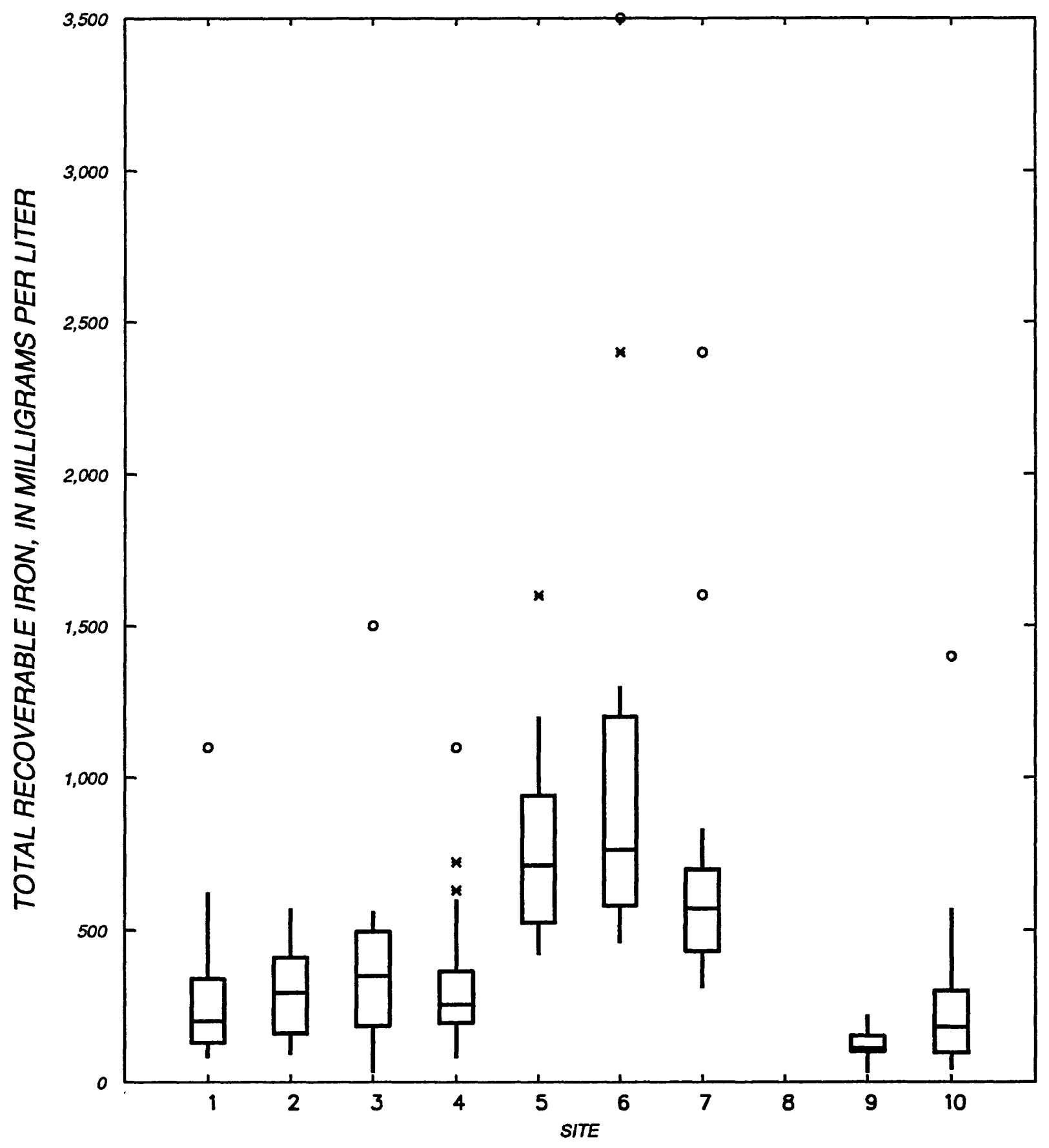

Figure 9.-- Box plot of total recoverable iron at selected sites in Lake Purdy drainage basin. 


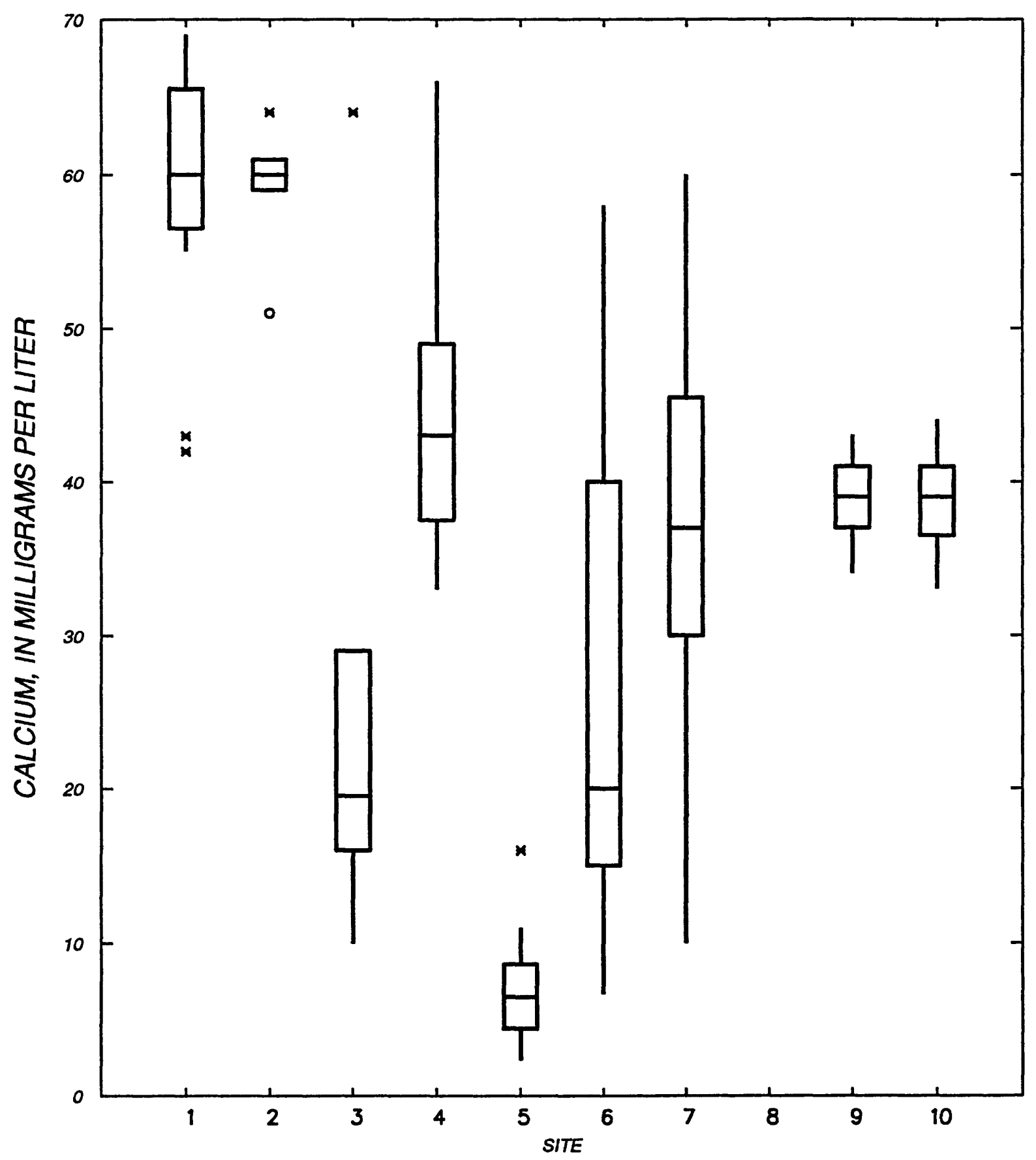

Figure 10.-- Box plot of calcium at selected sites in Lake Purdy drainage basin. 


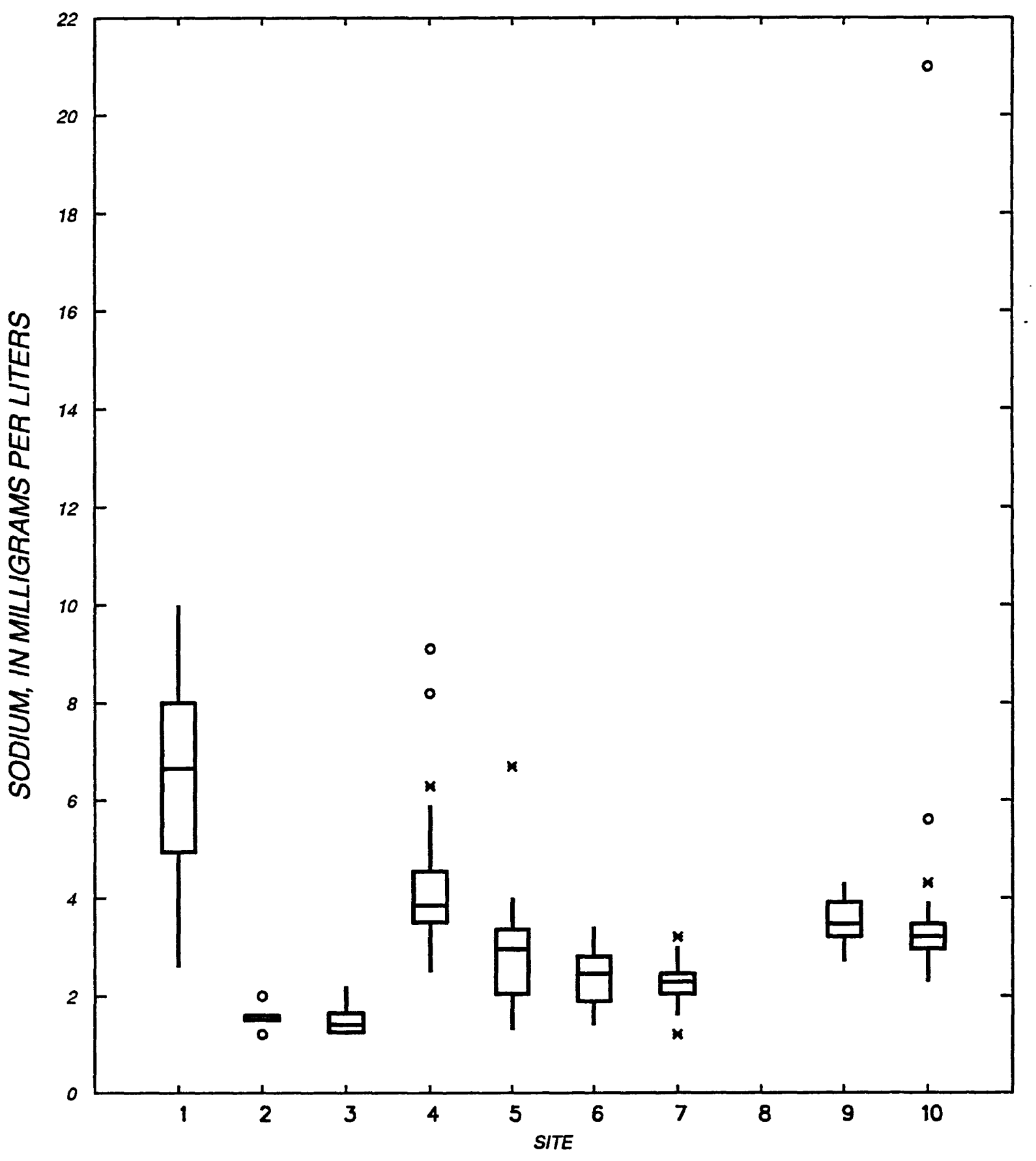

Figure 11.-- Box plot of sodium at selected sites in Lake Purdy drainage basin. 


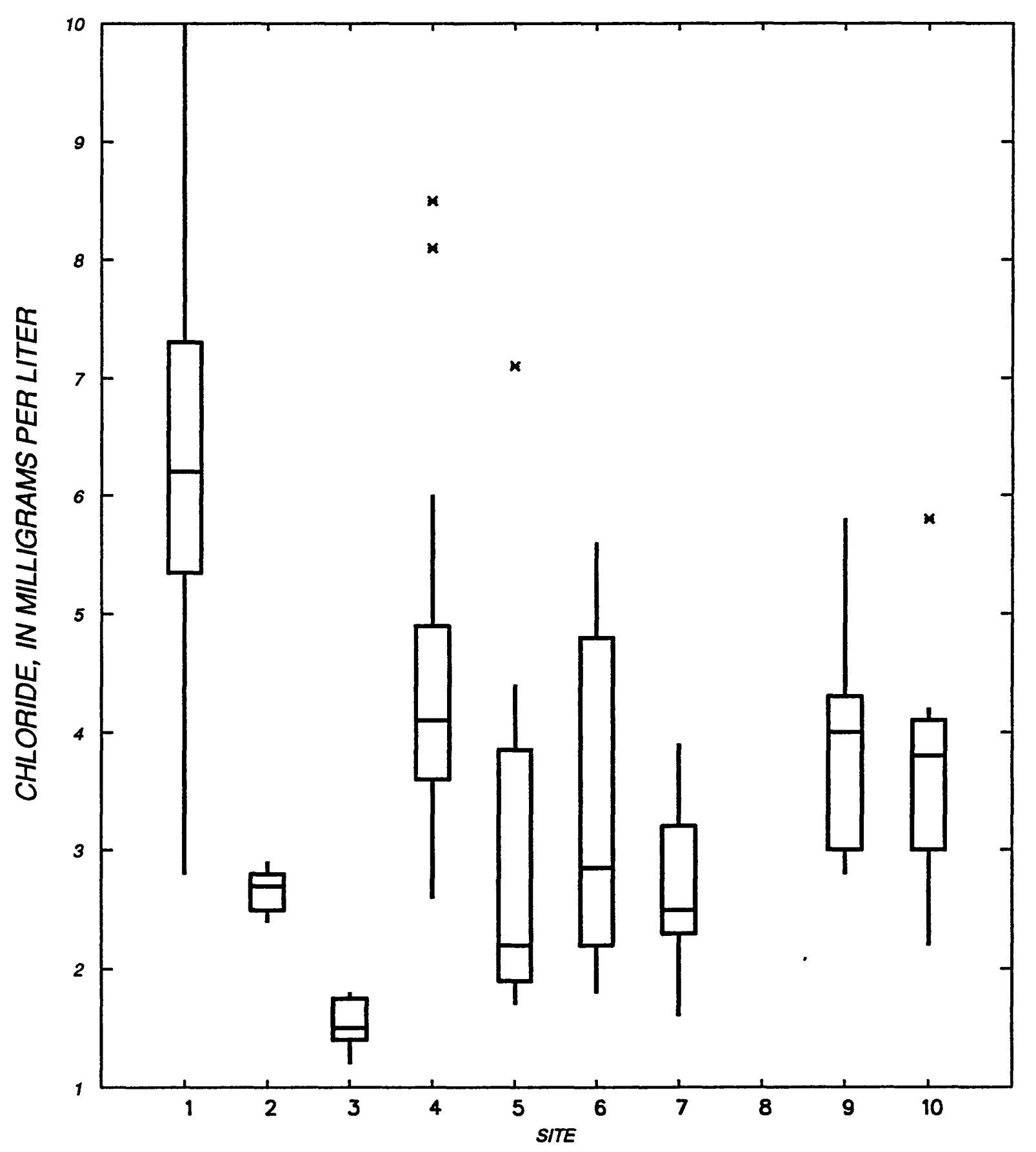

Figure 12.-- Box plot of chloride at selected sites in Lake Purdy drainage basin. 


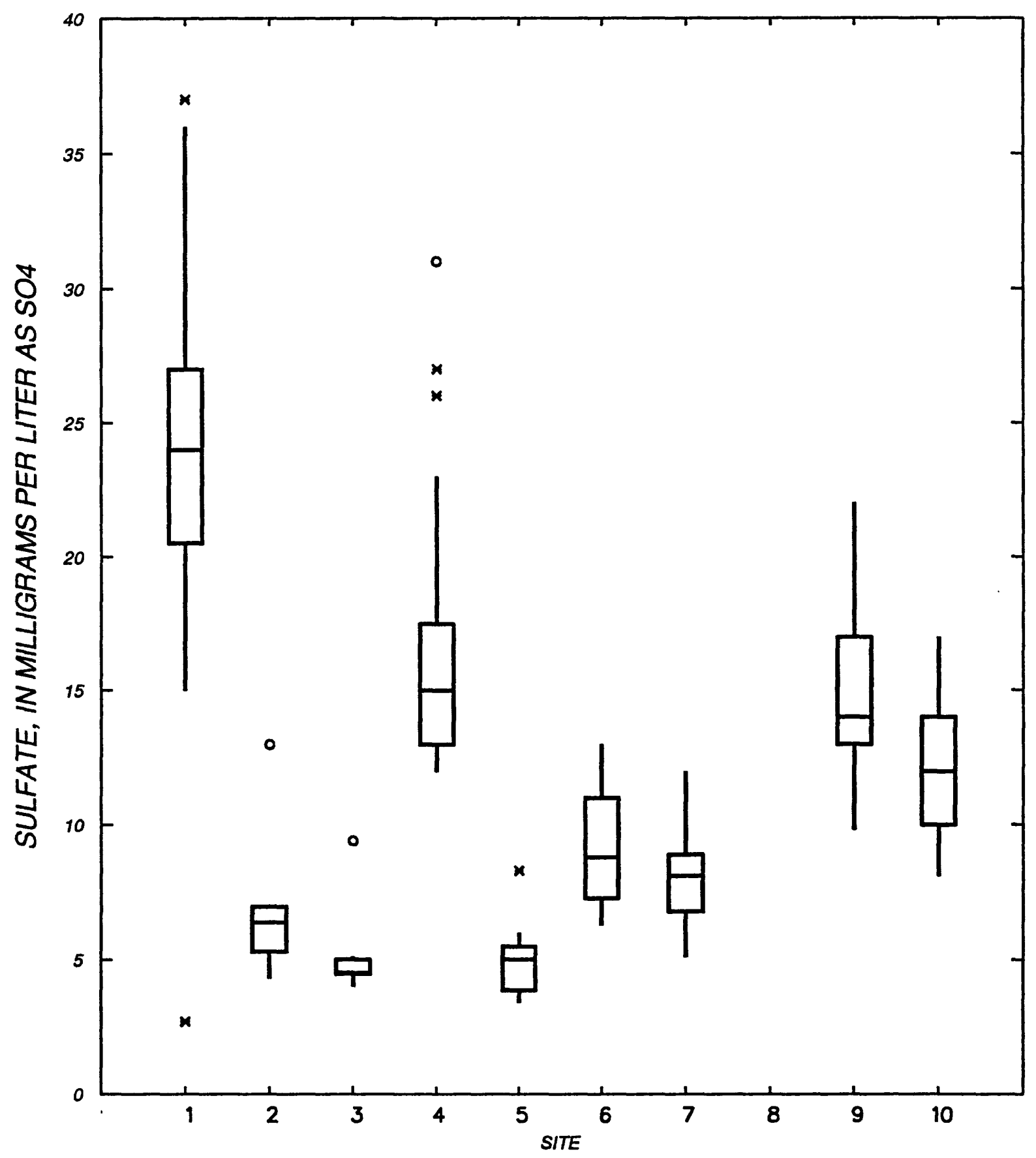

Figure 13.-- Box plot of sulfate at selected sites in Lake Purdy drainage basin. 
The southeastern part of Lake Purdy (site 7) has water chemistry that appears to be somewhat buffered from the influencing tributaries (Cox Creek, site 5; Lee Branch, site 6; unnamed tributary to Ike Pond Slough, site 8). The alkalinity, specific conductance, $\mathrm{pH}$, dissolved calcium and magnesium are all higher in the lake waters at this site than the tributaries. However, these parameters are lower at this southeast lake site than at the northern or southwestern site. The concentrations for sodium, chloride, and sulfate are similar for both the stream waters and the lake waters.

Cox Creek has the highest median dissolved iron concentrations and lowest $\mathrm{pH}$ in the basin. The difference in water chemistry for Cox Creek and, for some measurements, of Lee Branch can be seen in the Piper diagram on which all water-quality constituents for the Lake Purdy Basin from 1987 to 1991 are plotted (fig. 14). The outlying crosses (Cox Creek) and diamonds (Lee Branch) depict a more sulfate chloride-sodium magnesium rich water than the calciumbicarbonate waters of the other sites. The iron concentration of the lake at this southeastern site is also the highest as compared to the other lake sites. 
$\mathrm{x}$ - Cox Creek (site 5)

$\checkmark$ - Lee Branch (site 6)

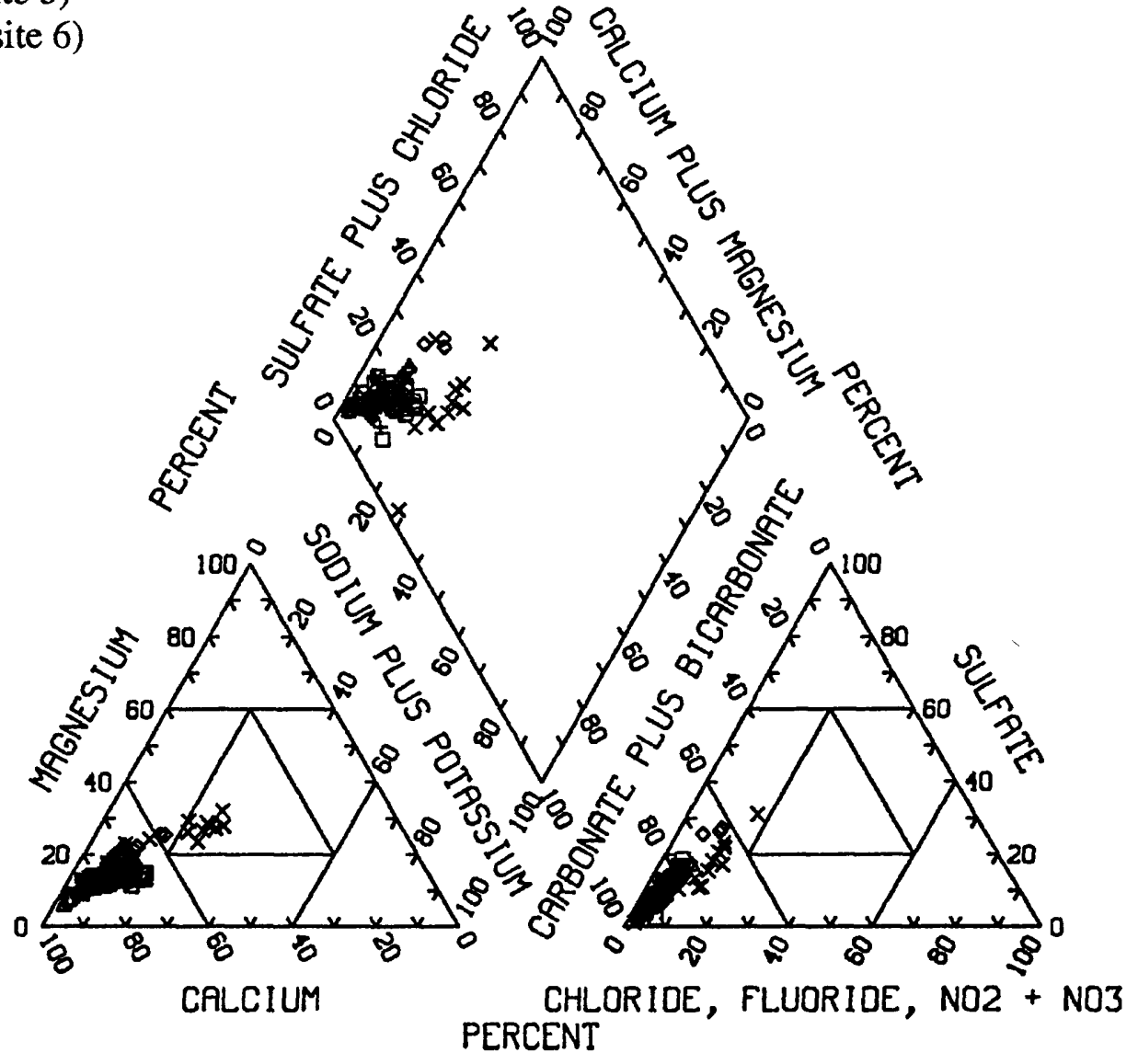

Figure 14.--Piper diagram of variation in water chemistry between Lake Purdy and selected tributaries sites for the period of record. 


\section{REFERENCES}

Butts, Charles, 1927, Description of the Bessemer-Vandiver quadrangles, Alabama:

U.S. Geological Survey Atlas, Folio 226.

Fenneman, N.M., 1938, Physiography of the eastern United States: New York, McGraw-Hill Book Company, $714 \mathrm{p}$.

Guy, H.P., and Norman, V.W., 1970, Field methods for measurement of fluvial sediment:

U.S. Geological Survey Techniques of Water-Resources Investigations, book 3, chap. C2, $50 \mathrm{p}$.

Johnston, W.D., Jr., 1933, Ground water in the Paleozoic rocks of northern Alabama:

U.S. Geological Survey Special Report 16, 414 p.

Kidd, J.T., 1979, Areal geology of Jefferson County, Alabama: Geological Survey of Alabama Atlas $15,89 \mathrm{p}$.

Klein, B., and Graedel, T.E., 1980, Emploratory data analysis in the geophysical sciences:

Reviews of geophysics and space physics, 18(3), p. 699-717.

Peirce, L.B., 1955, Hydrology and surface-water resources of east-central Alabama:

U.S. Geological Survey Special Report 22, p. 40-41.

Rantz, S.E., and others, 1982a, Measurement and computation of streamflow: Volume 1. Measurement of stage and discharge: U.S. Geological Survey Water-Supply Paper 2175, $284 \mathrm{p}$.

1982b, Measurement and computation of streamflow: Volume 2. Computation of discharge: U.S. Geological Survey Water-Supply Paper 2175, p. 285-631.

Riggs, H.G., 1969, Mean streamflow from discharge measurements: International Association of Science Hydrology Bulletin, v. XIV, no. 4, December 1969.

U.S. Department of Commerce, 1950-91, Climatological data for Alabama, National oceanic and Atmospheric Administration Climatological Data Reports (published monthly).

U.S. Environmental Protection Agency, 1986a, Secondary maximum contaminant levels (section 143.3 of part 143, national secondary drinking-water regulations): U.S. Code of Federal Regulations, Title 40, Parts 100 to 149 , revised as of July 1, 1986, p. 587-590. 1986b, Maximum contaminant levels (subpart B of part 141, national primary drinkingwater regulations): U.S. Code of Federal Regulations, Title 40, Parts 100 to 149, revised as of July 1, 1986, p. 524-528.

U.S. Geological Survey, 1988-92, Water resources data for Alabama, water years 1987-91-volume 1; U.S. Geological Survey Water-Data Reports AL-87-1 to AL-91-1 (published annually). 
Table 1.--Summary of surface-water data collection network [Site numbers correspond to those in figure 2]

\begin{tabular}{cllc}
\hline $\begin{array}{l}\text { Site } \\
\text { number }\end{array}$ & $\begin{array}{l}\text { USGS } \\
\text { station } \\
\text { number }\end{array}$ & \multicolumn{1}{c}{ Name } & $\begin{array}{c}\text { Drainage } \\
\text { area } \\
\text { (square miles) }\end{array}$ \\
\hline 1 & 02423400 & Little Cahaba River near Jefferson Park & 24.4 \\
2 & 02423403 & Unnamed tributary above Shephard Branch near Leeds & 1.05 \\
3 & 02423404 & Shephard Branch near Leeds & 2.24 \\
4 & 02423405 & Lake Purdy at Irondale Bridge near Leeds & 29.5 \\
5 & 0242340550 & Cox Creek near Cahaba Heights & 3.19 \\
6 & 0242340575 & Lee Branch near Cahaba Heights & 2.45 \\
7 & 02423406 & Lake Purdy at Highway 119 near Cahaba Heights & 6.69 \\
8 & 02423407 & Unnamed tributary to Ike Pond Slough near Cahaba Heights & 1.43 \\
9 & 02423409 & Lake Purdy near Cahaba Heights & 42.7 \\
10 & 02423410 & Little Cahaba River below Lake Purdy Dam & 42.7 \\
& & near Cahaba Heights & \\
\hline
\end{tabular}




\begin{tabular}{|c|c|c|}
\hline $\begin{array}{l}\text { Site } \\
\text { number }\end{array}$ & Station & $\begin{array}{l}\text { Annual mean } \\
\text { discharge } \\
\text { (cubic feet } \\
\text { per second) }\end{array}$ \\
\hline & 1987 Water Year & \\
\hline 1 & Little Cahaba River near Jefferson Park & 43.5 \\
\hline 5 & Cox Creek near Cahaba Heights & 5.1 \\
\hline 3 & Shephard Branch near Leeds & $2.3^{\mathrm{a}}$ \\
\hline 6 & Lee Branch near Cahaba Heights & $2.0^{\mathrm{a}}$ \\
\hline \multirow[t]{2}{*}{2} & Unnamed tributary above Shephard Branch near Leeds & $.7^{\mathrm{a}}$ \\
\hline & 1988 Water Year & \\
\hline 1 & Little Cahaba River near Jefferson Park & 19.4 \\
\hline 5 & Cox Creek near Cahaba Heights & 1.4 \\
\hline 3 & Shephard Branch near Leeds & $.7^{\mathrm{a}}$ \\
\hline 6 & Lee Branch near Cahaba Heights & $.2^{\mathrm{a}}$ \\
\hline \multirow[t]{2}{*}{2} & Unnamed tributary above Shephard Branch near Leeds & $.1^{\mathrm{a}}$ \\
\hline & 1989 Water Year & \\
\hline 1 & Little Cahaba River near Jefferson Park & 52.4 \\
\hline 5 & Cox Creek near Cahaba Heights & 4.5 \\
\hline 3 & Shephard Branch near Leeds & $3.0^{\mathrm{a}}$ \\
\hline 6 & Lee Branch near Cahaba Heights & $2.3^{\mathrm{a}}$ \\
\hline \multirow[t]{2}{*}{2} & Unnamed tributary above Shephard Branch near Leeds & $1.0^{\mathrm{a}}$ \\
\hline & 1990 Water Year & \\
\hline 1 & Little Cahaba River near Jefferson Park & 54.3 \\
\hline 6 & Lee Branch near Cahaba Heights & $7.2^{\mathrm{a}}$ \\
\hline 5 & Cox Creek near Cahaba Heights & 6.3 \\
\hline 2 & Shephard Branch near Leeds & $3.9^{\mathrm{a}}$ \\
\hline 3 & Unnamed tributary above Shephard Branch near Leeds & $1.9^{\mathrm{a}}$ \\
\hline
\end{tabular}

${ }^{a}$ Annual mean calculated from monthly means estimated by Riggs (1969) method. 
Table 3.--Summary of water-quality analyses at sampling sites in Lake Purdy Basin, water years 1987-91

$\left[\mathrm{mg} / \mathrm{L}\right.$, milligrams per liter; $\mu \mathrm{S} / \mathrm{cm}$, microsiemens per centimeter at $25^{\circ} \mathrm{C} ; \mu \mathrm{g} / \mathrm{L}$, micrograms per liter; ${ }^{\circ} \mathrm{C}$, degrees Celsius; $<$, less than]

02423400 Little Cahaba River near Jefferson Park

(Site 1 in figure 2)

Constituent or property

Alkalinity, field ( $\mathrm{mg} / \mathrm{L}$ as calcium carbonate)

Calcium, dissolved $(\mathrm{mg} / \mathrm{L}$ as $\mathrm{Ca})$

Chloride, dissolved ( $\mathrm{mg} / \mathrm{L}$ as $\mathrm{Cl}$ )

Fluoride, dissolved (mg/L as F)

Hardness $(\mathrm{mg} / \mathrm{L}$ as calcium carbonate

Magnesium, dissolved (mg/L)

Potassium, dissolved $(\mathrm{mg} / \mathrm{L})$

Silica, dissolved (mg/L as $\mathrm{SiO}_{2}$ )

Sodium, dissolved $(\mathrm{mg} / \mathrm{L})$

Solids, residue at $180^{\circ} \mathrm{C}$, dissolved $(\mathrm{mg} / \mathrm{L})$

Solids, sum of constituents (mg/L)

Sulfate, dissolved (mg/L)

$\mathrm{pH}$ (standard units)

Specific conductance $(\mu \mathrm{S} / \mathrm{cm})$

Nitrogen, $\mathrm{NO}_{2}$, total recoverable ( $\mathrm{mg} / \mathrm{L}$ as $\left.\mathrm{N}\right)$

Nitrogen, $\mathrm{NO}_{2}+\mathrm{NO}_{3}$, total recoverable (mg/L as $\mathrm{N}$ )

Nitrogen, $\mathrm{NH}_{3}$ torganic, total recoverable (mg/L as $\left.\mathrm{N}\right)$

Phosphorus, ortho, total recoverable (mg/L as $\mathrm{P}$ )

Phosphorus, total recoverable ( $\mathrm{mg} / \mathrm{L}$ as $\mathrm{P}$ )

Arsenic, dissolved $(\mu \mathrm{g} / \mathrm{L})$

Cadmium, dissolved $(\mu \mathrm{g} / \mathrm{L})$

Chromium, dissolved $(\mu \mathrm{g} / \mathrm{L})$

Iron, dissolved $(\mu \mathrm{g} / \mathrm{L})$

Lead, dissolved $(\mu \mathrm{g} / \mathrm{L})$

Manganese, dissolved $(\mu \mathrm{g} / \mathrm{L})$

Mercury, dissolved $(\mu \mathrm{g} / \mathrm{L})$

Selenium, dissolved $(\mu \mathrm{g} / \mathrm{L})$

Silver, dissolved $(\mu \mathrm{g} / \mathrm{L})$

Arsenic, total recoverable $(\mu \mathrm{g} / \mathrm{L})$

Cadmium, total recoverable $(\mu \mathrm{g} / \mathrm{L})$

Chromium, total recoverable $(\mu \mathrm{g} / \mathrm{L})$

Iron, total recoverable $(\mu \mathrm{g} / \mathrm{L})$

Lead, total recoverable $(\mu \mathrm{g} / \mathrm{L})$

Manganese, total recoverable $(\mu \mathrm{g} / \mathrm{L})$

Mercury, total recoverable $(\mu \mathrm{g} / \mathrm{L})$

Selenium, total recoverable $(\mu \mathrm{g} / \mathrm{L})$

Silver, total recoverable $(\mu \mathrm{g} / \mathrm{L})$
Range

\begin{tabular}{ccc}
\hline Minimum & Maximum & Median \\
\hline 43 & 202 & 163 \\
42 & 69 & 60
\end{tabular}

2.8

$<.1$

\section{8}

3.8

4.7

2.6

152

140

2.7

6.8

118

10

6.2

$200^{.2}$

180

.10

6.6

8.0

8.6

8.6

6.8

226

220

24

7.7

375

$$
.01
$$

.44

$<.20$

.01

.02

$<1$

$<1$

$<1$

$<10$

$<1$

$<10$

$<1$

$<1$

$<1$

$<1$

$<1$

$<1$

80

8

$<10$

$<.1$

$<1$

$<1$
37

455

.06

1.3

.55

.10

.13

$$
1
$$

1

$<1$

70

2

40

.1

$<1$

1

1

1

3

1,100

30

90

.2

$<1$

1

\section{.02}

.73

.29

.02

.05

$<1$

$<1$

--

20

$<5$

20

$<.1$

$<1$

$<1$

$<1$

$<1$

235

10

40

$<.1$

$-$

$<1$ 
Table 3.--Summary of water-quality analyses at sampling sites in Lake Purdy Basin, water years 1987-91--Continued

02423403 Unnamed Tributary above Shephard Branch near Leeds

(Site 2 in figure 2)

\begin{tabular}{|c|c|c|c|}
\hline \multirow[b]{2}{*}{ Constituent or property } & \multicolumn{2}{|c|}{ Range } & \multirow[b]{2}{*}{ Median } \\
\hline & Minimum & Maximum & \\
\hline Alkalinity, field (mg/L as calcium carbonate) & 92 & 210 & 160 \\
\hline Calcium, dissolved (mg/L as $\mathrm{Ca})$ & 51 & 64 & -- \\
\hline Chloride, dissolved (mg/L as $\mathrm{Cl}$ ) & 2.4 & 2.9 & 2.7 \\
\hline Fluoride, dissolved (mg/L as $\mathrm{F}$ ) & $<.1$ & .1 & .1 \\
\hline Hardness (mg/L as calcium carbonate) & 140 & 170 & -- \\
\hline Magnesium, dissolved (mg/L) & 2.7 & 3.3 & -- \\
\hline Potassium, dissolved $(\mathrm{mg} / \mathrm{L})$ & .5 & 1.3 & -- \\
\hline Silica, dissolved (mg/L as $\left.\mathrm{SiO}_{2}\right)$ & 6.4 & 7.9 & 6.8 \\
\hline Sodium, dissolved $(\mathrm{mg} / \mathrm{L})$ & 1.2 & 2.0 & 1.6 \\
\hline Solids, residue at $180^{\circ} \mathrm{C}$, dissolved $(\mathrm{mg} / \mathrm{L})$ & 161 & 200 & 190 \\
\hline Solids, sum of constituents (mg/L) & 151 & 189 & -- \\
\hline Sulfate, dissolved (mg/L) & 4.3 & 13 & 6.4 \\
\hline $\mathrm{pH}$ (standard units) & 7.2 & 8.3 & 7.7 \\
\hline Specific conductance $(\mu \mathrm{S} / \mathrm{cm})$ & 180 & 380 & 325 \\
\hline Nitrogen, $\mathrm{NO}_{2}$, total recoverable (mg/L as $\left.\mathrm{N}\right)$ & $<.01$ & .01 & $<.01$ \\
\hline Nitrogen, $\mathrm{NO}_{2}+\mathrm{NO}_{3}$, total recoverable $(\mathrm{mg} / \mathrm{L}$ as $\mathrm{N})$ & .02 & .30 & .05 \\
\hline Nitrogen, $\mathrm{NH}_{3}$ +organic, total recoverable $(\mathrm{mg} / \mathrm{L}$ as $\mathrm{N})$ & $<.20$ & .48 & .27 \\
\hline Phosphorus, ortho, total recoverable (mg/L as $\mathrm{P}$ ) & $<.01$ & .03 & .02 \\
\hline Phosphorus, total recoverable (mg/L as $\mathrm{P}$ ) & .02 & .06 & .04 \\
\hline Iron, dissolved $(\mu \mathrm{g} / \mathrm{L})$ & 20 & 60 & 20 \\
\hline Manganese, dissolved $(\mu \mathrm{g} / \mathrm{L})$ & $<10$ & 30 & 10 \\
\hline Iron, total recoverable $(\mu \mathrm{g} / \mathrm{L})$ & 90 & 570 & 295 \\
\hline Manganese, total recoverable $(\mu \mathrm{g} / \mathrm{L})$ & 20 & 70 & 50 \\
\hline
\end{tabular}


Table 3.--Summary of water-quality analyses at sampling sites in Lake Purdy Basin, water years 1987-91--Continued

02423404 Shephard Branch near Leeds

(Site 3 in figure 2)

Constituent or property

\begin{tabular}{ccc}
\multicolumn{2}{c}{ Range } & \\
\cline { 1 - 2 } Minimum & Maximum & Median \\
\cline { 1 - 2 } 15 & 220 & 67 \\
10 & 64 & 20 \\
1.2 & 1.8 & 1.5 \\
$<.1$ & .2 & .1 \\
30 & 170 & 56 \\
1.1 & 2.7 & 1.7 \\
.6 & .8 & .6 \\
7.4 & 8.9 & 8.3 \\
1.2 & 2.2 & 1.4 \\
48 & 182 & 80 \\
& & \\
4.0 & 9.4 & 4.5 \\
6.5 & 8.3 & 7.1 \\
45 & 400 & 146 \\
& & \\
$<.01$ & .01 & $<.01$ \\
$<.02$ & .17 & .05 \\
$<.20$ & .72 & $<.20$ \\
$<.01$ & .02 & .01 \\
$<.02$ & .08 & .02 \\
& & \\
$<10$ & 200 & 50 \\
$<10$ & 30 & 10 \\
30 & 1,500 & 350 \\
10 & 50 & 20
\end{tabular}

Alkalinity, field $(\mathrm{mg} / \mathrm{L}$ as calcium carbonate)

Calcium, dissolved $(\mathrm{mg} / \mathrm{L}$ as $\mathrm{Ca}$ )

Chloride, dissolved $(\mathrm{mg} / \mathrm{L}$ as $\mathrm{Cl})$

Fluoride, dissolved (mg/L as F)

Hardness (mg/L as calcium carbonate)

Magnesium, dissolved ( $\mathrm{mg} / \mathrm{L}$ )

Potassium, dissolved $(\mathrm{mg} / \mathrm{L})$

Silica, dissolved $\left(\mathrm{mg} / \mathrm{L}\right.$ as $\left.\mathrm{SiO}_{2}\right)$

Sodium, dissolved $(\mathrm{mg} / \mathrm{L})$

Solids, residue at $180^{\circ} \mathrm{C}$, dissolved $(\mathrm{mg} / \mathrm{L})$

Solids, sum of constituents $(\mathrm{mg} / \mathrm{L})$

$\mathrm{pH}$ (standard units)

Specific conductance $(\mu \mathrm{S} / \mathrm{cm})$

Nitrogen, $\mathrm{NO}_{2}$, total recoverable $(\mathrm{mg} / \mathrm{L}$ as $\mathrm{N})$

Nitrogen, $\mathrm{NO}_{2}+\mathrm{NO}_{3}$, total recoverable $(\mathrm{mg} / \mathrm{L}$ as $\mathrm{N})$

Nitrogen, $\mathrm{NH}_{3}$ +organic, total recoverable $(\mathrm{mg} / \mathrm{L}$ as $\mathrm{N}$ )

Phosphorus, ortho, total recoverable ( $\mathrm{mg} / \mathrm{L}$ as $\mathrm{P}$ )

Phosphorus, total recoverable (mg/L as P)

Iron, dissolved $(\mu \mathrm{g} / \mathrm{L})$

Manganese, dissolved $(\mu \mathrm{g} / \mathrm{L})$

Iron, total recoverable $(\mu \mathrm{g} / \mathrm{L})$

Manganese, total recoverable $(\mu \mathrm{g} / \mathrm{L})$ 
Table 3.--Summary of water-quality analyses at sampling sites in Lake Purdy Basin, water years 1987-91--Continued

02423405 Lake Purdy at Irondale Bridge near Leeds

(Site 4 in figure 2)

Constituent or property

Alkalinity, field (mg/L as calcium carbonate)

Calcium, dissolved (mg/L as $\mathrm{Ca}$ )

Chloride, dissolved ( $\mathrm{mg} / \mathrm{L}$ as $\mathrm{Cl}$ )

Fluoride, dissolved (mg/L as F)

Hardness (mg/L as calcium carbonate)

Magnesium, dissolved ( $\mathrm{mg} / \mathrm{L})$

Potassium, dissolved $(\mathrm{mg} / \mathrm{L})$

Silica, dissolved (mg/L as $\left.\mathrm{SiO}_{2}\right)$

Sodium, dissolved $(\mathrm{mg} / \mathrm{L})$

Solids, residue at $180^{\circ} \mathrm{C}$, dissolved $(\mathrm{mg} / \mathrm{L})$

Solids, sum of constituents (mg/L)

Sulfate, dissolved ( $\mathrm{mg} / \mathrm{L})$

$\mathrm{pH}$ (standard units)

Specific conductance $(\mu \mathrm{S} / \mathrm{cm})$

Nitrogen, $\mathrm{NO}_{2}$, recoverable $(\mathrm{mg} / \mathrm{L}$ as $\mathrm{N})$

Nitrogen, $\mathrm{NO}_{2}+\mathrm{NO}_{3}$, total recoverable $(\mathrm{mg} / \mathrm{L}$ as $\mathrm{N})$

Nitrogen, $\mathrm{NH}_{3}$ torganic, total recoverable (mg/L as $\mathrm{N}$ )

Phosphorus, ortho, total recoverable (mg/L as $\mathrm{P}$ )

Phosphorus, total recoverable ( $\mathrm{mg} / \mathrm{L}$ as $\mathrm{P}$ )

Arsenic dissolved $(\mu \mathrm{g} / \mathrm{L})$

Cadmium, dissolved $(\mu \mathrm{g} / \mathrm{L})$

Chromium, dissolved $(\mu \mathrm{g} / \mathrm{L})$

Iron, dissolved $(\mu \mathrm{g} / \mathrm{L})$

Lead, dissolved $(\mu \mathrm{g} / \mathrm{L})$

Manganese, dissolved $(\mu \mathrm{g} / \mathrm{L})$

Mercury, dissolved $(\mu \mathrm{g} / \mathrm{L})$

Selenium, dissolved $(\mu \mathrm{g} / \mathrm{L})$

Silver, dissolved $(\mu \mathrm{g} / \mathrm{L})$

Arsenic, total recoverable $(\mu \mathrm{g} / \mathrm{L})$

Cadmium, total recoverable $(\mu \mathrm{g} / \mathrm{L})$

Chromium, total recoverable $(\mu \mathrm{g} / \mathrm{L})$

Iron, total recoverable $(\mu \mathrm{g} / \mathrm{L})$

Lead, total recoverable $(\mu \mathrm{g} / \mathrm{L})$

Manganese, total recoverable $(\mu \mathrm{g} / \mathrm{L})$

Mercury, total recoverable $(\mu \mathrm{g} / \mathrm{L})$

Selenium, total recoverable $(\mu \mathrm{g} / \mathrm{L})$

Silver, total recoverable $(\mu \mathrm{g} / \mathrm{L})$
Range

\begin{tabular}{ccc}
\cline { 1 - 2 } Minimum & Maximum & Median \\
\hline 90 & 180 & 120 \\
36 & 65 & 44 \\
2.6 & 12 & 4.0 \\
$<.1$ & .2 & .1 \\
100 & 190 & 130 \\
3.3 & 8.4 & 4.8 \\
3.2 & 19 & 5.0 \\
.3 & 10 & 5.7 \\
2.5 & 12 & 3.8 \\
128 & 252 & 154 \\
& & \\
121 & 243 & 147 \\
12 & 41 & 15 \\
7.1 & 8.6 & 7.9 \\
122 & 415 & 256
\end{tabular}

$\begin{array}{ccc}<.01 & .02 & .01 \\ <.02 & 1.1 & .19 \\ .23 & 1.0 & .46 \\ .01 & .04 & .02 \\ .02 & .14 & .05\end{array}$

$<1$

$<1$

$<1$

$<10$

$<1$

$<10$

$<.10$

$<1$

$<1$

$<1$

$<1$

$<1$

120

$<5$

20

$<.10$

$<1$

$<1$

\section{0}

$<1$

$<1$

140

2

90

.10

$<1$

1

1.0

1.0

$$
7
$$

1,100

60

140

$<.1$

$<1$

4
$<1$

$<1$

$<5$

10

$<.10$

$<1$

$<1$

1.0

$<1.0$

$-$

280

10

45

$<.10$

$<1$ 
Table 3.--Summary of water-quality analyses at sampling sites in Lake Purdy Basin, water years 1987-91--Continued

0242340550 Cox Creek near Cahaba Heights

(Site 5 in figure 2)

Constituent or property

Range

Minimum Maximum Median

Alkalinity, field ( $\mathrm{mg} / \mathrm{L}$ as calcium carbonate)

Calcium, dissolved $(\mathrm{mg} / \mathrm{L}$ as $\mathrm{Ca})$

Chloride, dissolved $(\mathrm{mg} / \mathrm{L}$ as $\mathrm{Cl})$

Fluoride, dissolved ( $\mathrm{mg} / \mathrm{L}$ as $\mathrm{F}$ )

Hardness ( $\mathrm{mg} / \mathrm{L}$ as calcium carbonate)

Magnesium, dissolved (mg/L)

Potassium, dissolved $(\mathrm{mg} / \mathrm{L})$

$\begin{array}{lll}8 & 66 & 17\end{array}$

Silica, dissolved (mg/L as $\mathrm{SiO}_{2}$ )

Sodium, dissolved $(\mathrm{mg} / \mathrm{L})$

Solids, residue at $180^{\circ} \mathrm{C}$, dissolved $(\mathrm{mg} / \mathrm{L})$

2.3

1.7

11

17

$<.1$

10

1.1

$\begin{array}{rr}7 & 4.4 \\ 1 & .2\end{array}$

5.4

2.0

41

.8

13.4

2.9

$7.3 \quad 8.6$

1.3

28

3.6

7.6

2.4

61

38

Solids, sum of constituents (mg/L)

Sulfate, dissolved $(\mathrm{mg} / \mathrm{L})$

$25 \quad 62$

3.4

62

36

$\mathrm{pH}$ (standard units)

5.9

Specific conductance $(\mu \mathrm{S} / \mathrm{cm})$

32

7.3

185

4.8

6.6

60

Nitrogen, $\mathrm{NO}_{2}$, total recoverable $(\mathrm{mg} / \mathrm{L}$ as $\mathrm{N})$

Nitrogen, $\mathrm{NO}_{2}+\mathrm{NO}_{3}$, total recoverable (mg/L as N)

Nitrogen, $\mathrm{NH}_{3}$ +organic, total recoverable (mg/L as $\mathrm{N}$ )

Phosphorus, ortho, total recoverable $(\mathrm{mg} / \mathrm{L}$ as $\mathrm{P})$

Phosphorus, total recoverable ( $\mathrm{mg} / \mathrm{L}$ as $\mathrm{P}$ )

$<.01$

.04

$<.20$

.01

.02

.02

.01

.08

2.0

.31

.05

.02

.09

.04

Iron, dissolved $(\mu \mathrm{g} / \mathrm{L})$

Manganese, dissolved $(\mu \mathrm{g} / \mathrm{L})$

160

20

70

40

Iron, total recoverable $(\mu \mathrm{g} / \mathrm{L})$

Manganese, total recoverable $(\mu \mathrm{g} / \mathrm{L})$

$430 \quad 1,100$

$30 \quad 100$

710

70 
Table 3.--Summary of water-quality analyses at sampling sites in Lake Purdy Basin, water years 1987-91--Continued

0242340575 Lee Branch near Cahaba Heights

(Site 6 in figure 2)

\section{Constituent or property}

Alkalinity, field ( $\mathrm{mg} / \mathrm{L}$ as calcium carbonate)

Calcium, dissolved $(\mathrm{mg} / \mathrm{L}$ as $\mathrm{Ca}$ )

Chloride, dissolved ( $\mathrm{mg} / \mathrm{L}$ as $\mathrm{Cl})$

Fluoride, dissolved ( $\mathrm{mg} / \mathrm{L}$ as $\mathrm{F}$ )

Hardness $(\mathrm{mg} / \mathrm{L}$ as calcium carbonate)

Magnesium, dissolved $(\mathrm{mg} / \mathrm{L})$

Potassium, dissolved $(\mathrm{mg} / \mathrm{L})$

Silica, dissolved $\left(\mathrm{mg} / \mathrm{L}\right.$ as $\left.\mathrm{SiO}_{2}\right)$

Sodium, dissolved $(\mathrm{mg} / \mathrm{L})$

Solids, residue at $180^{\circ} \mathrm{C}$, dissolved $(\mathrm{mg} / \mathrm{L})$

Solids, sum of constituents $(\mathrm{mg} / \mathrm{L})$

Sulfate, dissolved $(\mathrm{mg} / \mathrm{L})$

$\mathrm{pH}$ (standard units)

Specific conductance $(\mu \mathrm{S} / \mathrm{cm})$

Nitrogen, $\mathrm{NO}_{2}$, total recoverable (mg/L as $\mathrm{N}$ )

Nitrogen, $\mathrm{NO}_{2}+\mathrm{NO}_{3}$, total recoverable $(\mathrm{mg} / \mathrm{L}$ as $\mathrm{N}$ )

Nitrogen, $\mathrm{NH}_{3}$ +organic, total recoverable $(\mathrm{mg} / \mathrm{L}$ as $\mathrm{N})$

Phosphorus, ortho, total recoverable $(\mathrm{mg} / \mathrm{L}$ as $\mathrm{P}$ )

Phosphorus, total recoverable $(\mathrm{mg} / \mathrm{L}$ as $\mathrm{P})$

Iron, dissolved $(\mu \mathrm{g} / \mathrm{L})$

Manganese, dissolved $(\mu \mathrm{g} / \mathrm{L})$

Iron, total recoverable $(\mu \mathrm{g} / \mathrm{L})$

Manganese, total recoverable $(\mu \mathrm{g} / \mathrm{L})$
Range

$\overline{\text { Minimum Maximum }}$

15

6.7

1.8

$<.1$

24

1.8

1.0

3.4

1.4

47

157

58

5.6

.2

160

4.1

2.6

7.5

3.4

185

37

6.3

6.1

52

182

13

7.6

305

$<.01$

$<.02$

$<.20$

$<.01$

.02

30

20

170

350

.03

.78

.50

.08

.08

Median

59

16

2.3

$<.1$

51

2.8

1.4

6.2

2.1

70

66

8.8

6.8

148

460

3,500

30

380
.01

.07

.26

.02

.04

75

50

760

75 
Table 3.--Summary of water-quality analyses at sampling sites in Lake Purdy Basin, water years 1987-91--Continued

02423406 Lake Purdy at Highway 119 near Cahaba Heights

(Site 7 in figure 2)

Constituent or property

Range

Minimum Maximum

Median

Alkalinity, field ( $\mathrm{mg} / \mathrm{L}$ as calcium carbonate)

Calcium, dissolved $(\mathrm{mg} / \mathrm{L}$ as $\mathrm{Ca})$

Chloride, dissolved $(\mathrm{mg} / \mathrm{L}$ as $\mathrm{Cl})$

Fluoride, dissolved $(\mathrm{mg} / \mathrm{L}$ as $\mathrm{F})$

Hardness $(\mathrm{mg} / \mathrm{L}$ as calcium carbonate)

Magnesium, dissolved ( $\mathrm{mg} / \mathrm{L})$

Potassium, dissolved $(\mathrm{mg} / \mathrm{L})$

Silica, dissolved $\left(\mathrm{mg} / \mathrm{L}\right.$ as $\left.\mathrm{SiO}_{2}\right)$

Sodium, dissolved $(\mathrm{mg} / \mathrm{L})$

Solids, residue at $180^{\circ} \mathrm{C}$, dissolved $(\mathrm{mg} / \mathrm{L})$

Solids, sum of constituents ( $\mathrm{mg} / \mathrm{L}$ )

Sulfate, dissolved $(\mathrm{mg} / \mathrm{L})$

$\mathrm{pH}$ (standard units)

Specific conductance $(\mu \mathrm{S} / \mathrm{cm})$

Nitrogen, $\mathrm{NO}^{2}$, total recoverable $(\mathrm{mg} / \mathrm{L}$ as $\mathrm{N})$

Nitrogen, $\mathrm{NO}_{2}+\mathrm{NO}_{3}$, total recoverable $(\mathrm{mg} / \mathrm{L}$ as $\mathrm{N})$

Nitrogen, $\mathrm{NH}_{3}$ +organic, total recoverable (mg/L as $\mathrm{N}$ )

Phosphorus, ortho, total recoverable ( $\mathrm{mg} / \mathrm{L}$ as $\mathrm{P})$

Phosphorus, total recoverable $(\mathrm{mg} / \mathrm{L}$ as $\mathrm{P}$ )

Arsenic, dissolved $(\mu \mathrm{g} / \mathrm{L})$

Cadmium, dissolved $(\mu \mathrm{g} / \mathrm{L})$

Chromium, dissolved $(\mu \mathrm{g} / \mathrm{L})$

Iron, dissolved $(\mu \mathrm{g} / \mathrm{L})$

Lead, dissolved $(\mu \mathrm{g} / \mathrm{L})$

Manganese, dissolved $(\mu \mathrm{g} / \mathrm{L})$

Mercury, dissolved $(\mu \mathrm{g} / \mathrm{L})$

Selenium, dissolved $(\mu \mathrm{g} / \mathrm{L})$

Silver, dissolved $(\mu \mathrm{g} / \mathrm{L})$

Arsenic, total recoverable $(\mu \mathrm{g} / \mathrm{L})$

Cadmium, total recoverable $(\mu \mathrm{g} / \mathrm{L})$

Chromium, total recoverable $(\mu \mathrm{g} / \mathrm{L})$

Iron, total recoverable $(\mu \mathrm{g} / \mathrm{L})$

Lead, total recoverable $(\mu \mathrm{g} / \mathrm{L})$

Manganese, total recoverable $(\mu \mathrm{g} / \mathrm{L})$

Mercury, total recoverable $(\mu \mathrm{g} / \mathrm{L})$

Selenium, total recoverable $(\mu \mathrm{g} / \mathrm{L})$

Silver, total recoverable $(\mu \mathrm{g} / \mathrm{L})$
25

10

1.6

$<.1$

31

1.4

.7

3.0

1.2

51

42

5.6

6.3

87

160

60

3.9

101

38

2.5

110

170

5.2

3.4

7.7

3.2

189

129

2.2

120

183

7.2

8.5

7.6

230

$<.01$

$<.02$

.27

$<.01$

.02

325

$<.01$

.02

$\begin{array}{ccc}<1 & <1 & <1 \\ <1 & <1 & <1 \\ <1 & 2 & -- \\ <10 & 120 & 20 \\ <1 & <5 & <5 \\ <10 & 180 & 30 \\ <.10 & .10 & <.10 \\ <1 & <1 & -- \\ <1 & 1 & <1\end{array}$

$<1$

$<1$

1

310

$<5$

20

$<.10$

$<1$

$<1$
.35

.01

.04

1.3

.03

.18

$<1$

$<1$

--

570

$<5$

90

$<.10$

$<1$ 
Table 3.--Summary of water-quality analyses at sampling sites in Lake Purdy Basin, water years 1987-91--Continued

02423407 Unnamed Tributary to Ike Pond Slough near Cahaba Heights (Site 8 in figure 2)

Constituent or property

Alkalinity, field $(\mathrm{mg} / \mathrm{L}$ as calcium carbonate)

Calcium, dissolved $(\mathrm{mg} / \mathrm{L}$ as $\mathrm{Ca})$

Chloride, dissolved ( $\mathrm{mg} / \mathrm{L}$ as $\mathrm{Cl}$ )

Fluoride, dissolved (mg/L as F)

Hardness ( $\mathrm{mg} / \mathrm{L}$ as calcium carbonate)

Magnesium, dissolved ( $\mathrm{mg} / \mathrm{L}$ )

Potassium, dissolved $(\mathrm{mg} / \mathrm{L})$

Silica, dissolved $\left(\mathrm{mg} / \mathrm{L}\right.$ as $\left.\mathrm{SiO}_{2}\right)$

Sodium, dissolved $(\mathrm{mg} / \mathrm{L})$

Solids, residue at $180^{\circ} \mathrm{C}$, dissolved $(\mathrm{mg} / \mathrm{L})$

Solids, sum of constituents ( $\mathrm{mg} / \mathrm{L}$ )

Sulfate, dissolved $(\mathrm{mg} / \mathrm{L})$

$\mathrm{pH}$ (standard units)

Specific conductance $(\mu \mathrm{S} / \mathrm{cm})$

Nitrogen, $\mathrm{NO}_{2}$, total recoverable $(\mathrm{mg} / \mathrm{L}$ as $\mathrm{N})$

Nitrogen, $\mathrm{NO}_{2}+\mathrm{NO}_{3}$, total recoverable $(\mathrm{mg} / \mathrm{L}$ as $\mathrm{N})$

Nitrogen, $\mathrm{NH}_{3}+$ organic, total recoverable $(\mathrm{mg} / \mathrm{L}$ as $\mathrm{N}$ )

Phosphorus, ortho, total recoverable $(\mathrm{mg} / \mathrm{L}$ as $\mathrm{P})$

Phosphorus, total recoverable $(\mathrm{mg} / \mathrm{L}$ as $\mathrm{P})$

Iron, dissolved $(\mu \mathrm{g} / \mathrm{L})$

Manganese, dissolved $(\mu \mathrm{g} / \mathrm{L})$

Iron, total recoverable $(\mu \mathrm{g} / \mathrm{L})$

Manganese, total recoverable $(\mu \mathrm{g} / \mathrm{L})$
Range

Minimum Maximum Median

$\begin{array}{ccc}10 & 108 & 61 \\ 17 & 26 & - \\ 1.6 & 1.9 & - \\ <.1 & .2 & - \\ 50 & 74 & - \\ 1.8 & 2.3 & - \\ .4 & 1.3 & - \\ 5.2 & 6.8 & - \\ .50 & 1.1 & - \\ 64 & 81 & -\end{array}$

61

3.0

6.0

31

86

5.9

7.3

$-$

6.7

138

$\begin{array}{rll}.02 & .11 & - \\ .02 & .12 & - \\ <.20 & .33 & - \\ <.01 & .04 & - \\ <.02 & .03 & -\end{array}$

$\begin{array}{rrr}40 & 100 & - \\ <10 & 50 & -\end{array}$

100

20

$1,100 \quad--$
$120 \quad--$


Table 3.--Summary of water-quality analyses at sampling sites in Lake Purdy Basin, water years 1987-91--Continued

02423409 Lake Purdy near Cahaba Heights

(Site 9 in figure 2)

Constituent or property

Alkalinity, field ( $\mathrm{mg} / \mathrm{L}$ as calcium carbonate)

Calcium, dissolved $(\mathrm{mg} / \mathrm{L}$ as $\mathrm{Ca})$

Chloride, dissolved $(\mathrm{mg} / \mathrm{L}$ as $\mathrm{Cl})$

Fluoride, dissolved ( $\mathrm{mg} / \mathrm{L}$ as $\mathrm{F}$ )

Hardness $(\mathrm{mg} / \mathrm{L}$ as calcium carbonate)

Magnesium, dissolved ( $\mathrm{mg} / \mathrm{L}$ )

Potassium, dissolved $(\mathrm{mg} / \mathrm{L})$

Silica, dissolved $\left(\mathrm{mg} / \mathrm{L}\right.$ as $\left.\mathrm{SiO}_{2}\right)$

Sodium, dissolved $(\mathrm{mg} / \mathrm{L})$

Solids, residue at $180^{\circ} \mathrm{C}$, dissolved $(\mathrm{mg} / \mathrm{L})$

Solids, sum of constituents (mg/L)

Sulfate, dissolved $(\mathrm{mg} / \mathrm{L})$

$\mathrm{pH}$ (standard units)

Specific conductance $(\mu \mathrm{S} / \mathrm{cm})$

Range

Minimum Maximum Median

$\begin{array}{ccc}64 & 130 & 110 \\ 29 & 43 & 39 \\ 2.8 & 6.8 & 4.0 \\ <.1 & .3 & .1 \\ 98 & 140 & 120 \\ 3.6 & 8.6 & 5.3 \\ 2.9 & 6.8 & 4.5 \\ <.10 & 8.1 & 4.9 \\ 2.7 & 5.3 & 3.5 \\ 121 & 163 & 144 \\ & & \\ 121 & 155 & 140 \\ 9.8 & 22 & 14 \\ 6.9 & 8.6 & 7.6 \\ 153 & 298 & 235\end{array}$

Nitrogen, $\mathrm{NO}_{2}$, total recoverable $(\mathrm{mg} / \mathrm{L}$ as $\mathrm{N})$

Nitrogen, $\mathrm{NO}_{2}+\mathrm{NO}_{3}$, total recoverable $(\mathrm{mg} / \mathrm{L}$ as $\mathrm{N})$

$.02 \quad .18$

.09

$<.02$

.19

.02

Nitrogen, $\mathrm{NH}_{3}$ +organic, total recoverable $(\mathrm{mg} / \mathrm{L}$ as $\mathrm{N})$

$<.20$

.68

.40

Phosphorus, ortho, total recoverable ( $\mathrm{mg} / \mathrm{L}$ as $\mathrm{P}$ )

Phosphorus, total recoverable $(\mathrm{mg} / \mathrm{L}$ as $\mathrm{P}$ )

$<.01$

.02

.01

.02

.12

Arsenic, dissolved $(\mu \mathrm{g} / \mathrm{L})$

Cadmium, dissolved $(\mu \mathrm{g} / \mathrm{L})$

$\begin{array}{ccc}<1 & <1 & <1 \\ <1 & <1 & <1 \\ <1 & 2 & -- \\ <10 & 140 & 10 \\ <1 & <5 & <5 \\ <10 & 10 & <10 \\ <.10 & <.1 & <.10 \\ <1 & <1 & -- \\ <1 & 1 & --\end{array}$

Iron, dissolved $(\mu \mathrm{g} / \mathrm{L})$

Lead, dissolved $(\mu \mathrm{g} / \mathrm{L})$

Manganese, dissolved $(\mu \mathrm{g} / \mathrm{L})$

Mercury, dissolved $(\mu \mathrm{g} / \mathrm{L})$

Selenium, dissolved $(\mu \mathrm{g} / \mathrm{L})$

Silver, dissolved $(\mu \mathrm{g} / \mathrm{L})$

Arsenic, total recoverable $(\mu \mathrm{g} / \mathrm{L})$

Cadmium, total recoverable $(\mu \mathrm{g} / \mathrm{L})$

Chromium, total recoverable $(\mu \mathrm{g} / \mathrm{L})$

Iron, total recoverable $(\mu \mathrm{g} / \mathrm{L})$

Lead, total recoverable $(\mu \mathrm{g} / \mathrm{L})$

Manganese, total recoverable $(\mu \mathrm{g} / \mathrm{L})$

Mercury, total recoverable $(\mu \mathrm{g} / \mathrm{L})$

Selenium, total recoverable $(\mu \mathrm{g} / \mathrm{L})$

Silver, total recoverable $(\mu \mathrm{g} / \mathrm{L})$

$\begin{array}{ccc}<1 & 1 & <1 \\ <1 & 1 & <1 \\ <1 & 6 & -- \\ 30 & 220 & 115 \\ <5 & 7 & 2 \\ <10 & 50 & 30 \\ <.10 & <.1 & <.10 \\ <1 & <1 & <1 \\ <1 & 1 & --\end{array}$


Table 3.--Summary of water-quality analyses at sampling sites in Lake Purdy Basin, water years 1987-91--Continued

02423410 Little Cahaba River below Lake Purdy Dam near Cahaba Heights (Site 10 in figure 2)

Constituent or property
Alkalinity, field (mg/L as calcium carbonate)
Calcium, dissolved (mg/L as $\mathrm{Ca})$
Chloride, dissolved $(\mathrm{mg} / \mathrm{L}$ as $\mathrm{Cl})$
Fluoride, dissolved $(\mathrm{mg} / \mathrm{L}$ as $\mathrm{F})$
Hardness (mg/L as calcium carbonate)
Magnesium, dissolved $(\mathrm{mg} / \mathrm{L})$
Potassium, dissolved $(\mathrm{mg} / \mathrm{L})$
Silica, dissolved (mg/L as $\mathrm{SiO} / 2)$
Sodium, dissolved $(\mathrm{mg} / \mathrm{L})$
Solids, residue at $180^{\circ} \mathrm{C}$, dissolved (mg/L)
Solids, sum of constituents $(\mathrm{mg} / \mathrm{L})$
Sulfate, dissolved $(\mathrm{mg} / \mathrm{L})$
pH (standard units)
Specific conductance $(\mu \mathrm{S} / \mathrm{cm})$

Nitrogen, $\mathrm{NO}_{2}$, total recoverable $(\mathrm{mg} / \mathrm{L}$ as $\mathrm{N})$

Nitrogen, $\mathrm{NO}_{2}+\mathrm{NO}_{3}$, total recoverable $(\mathrm{mg} / \mathrm{L}$ as $\mathrm{N})$

Nitrogen, $\mathrm{NH}_{3}$ +organic, total recoverable $(\mathrm{mg} / \mathrm{L}$ as $\mathrm{N})$

Phosphorus, ortho, total recoverable ( $\mathrm{mg} / \mathrm{L}$ as $\mathrm{P})$

Phosphorus, total recoverable $(\mathrm{mg} / \mathrm{L}$ as $\mathrm{P})$

Arsenic, dissolved $(\mu \mathrm{g} / \mathrm{L})$

Cadmium, dissolved $(\mu \mathrm{g} / \mathrm{L})$

Chromium, dissolved $(\mu \mathrm{g} / \mathrm{L})$

Iron, dissolved $(\mu \mathrm{g} / \mathrm{L})$

Lead, dissolved $(\mu \mathrm{g} / \mathrm{L})$

Manganese, dissolved $(\mu \mathrm{g} / \mathrm{L})$

Mercury, dissolved $(\mu \mathrm{g} / \mathrm{L})$

Selenium, dissolved $(\mu \mathrm{g} / \mathrm{L})$

Silver, dissolved $(\mu \mathrm{g} / \mathrm{L})$

$\frac{\text { Range }}{\text { Minimum Maximum }}$

